\title{
ARTICLES
}

\section{THE TRANSPARENCY FiX: ADVOCATING LEGAL RIGHTS AND THEIR ALTERNATIVES IN THE PURSUIT OF A VISIBLE STATE}

\author{
Mark Fenster ${ }^{*}$
}

\begin{abstract}
The administrative norm of transparency, which promises a solution to the problem of government secrecy, requires political advocacy organized from outside the state. The traditional approach, typically the result of organized campaigns to make the state visible to the public, has been to enact freedom of information laws (FOI) that require government disclosure and grant enforceable rights to the public. The legal solution has not proven wholly satisfactory, however. In the past two decades, numerous advocacy movements have offered different fixes to the information asymmetry problem that the administrative state creates. These alternatives now augment and sometimes compete with legal transparency regimes. This article surveys and analyzes transparency advocacy campaigns and the "fix" that each proposes to the problems created by the state's asymmetrical information advantage over the public. It sketches the history of four campaigns: the FOI movement in the United States, the global anti-corruption movement (spearheaded by Transparency International), the digital-transparency movement, and the advent of WikiLeaks.
\end{abstract}

\footnotetext{
* Professor and Samuel T. Dell Research Scholar, Levin College of Law, University of Florida. Thanks to David Fontana, Rachel Rebouché, Steven Sampson, and Trysh Travis for comments and suggestions. I presented an early version of this article at the First Global Conference on Transparency Research at Rutgers University-Newark, and want to thank attendees for valuable feedback.
} 
U N I V E R S I T Y O F P I T T S B U R G H L A W R E V I E W

PAGE

The article offers two insights: First, although these movements share a basic set of assumptions and tell a similar policy story—secrecy is a pressing administrative problem that can be fixed with the right policies and institutional arrangements - they diverge significantly in how they understand not only the problem's causes but the state itself. Second, the article unveils transparency as a contested political issue that masquerades as an administrative tool. Rooted in contestable claims about the state's legitimacy and performance, the transparency fix leads to tendentious prescriptions about law, policy, and the state. 


\section{Table of Contents}

Introduction: The Information Asymmetry Problem .446

I. The Legal Rights Fix: FOIA and the Origins of the "Right to Know" and "Freedom of Information"

A. Exporting Rights and Freedoms...............................................451

B. The Right to Know and Freedom of Information, from Press Ideals to Legal Informational Rights. 458

C. The Political Enactment of Legal Informational Rights .461

D. Conclusion: The Limits of Law .466

II. The Administrative and Institutional Fix: Anti-Corruption as Transparency . .468

A. "Transparency" in Transparency International ................................471

B. The Contestable Claims of the Institutional Anti-Corruption Fix........474

C. Conclusion: The Limits of the Institutional Anti-Corruption Fix ........477

III. The Technological Fix: Digital Transparency .... .478

A. Digital Transparency and the Technological Transformation of State and Public .479

B. The Limits of the Technological Fix...............................................487

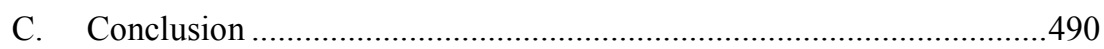

IV. The Vigilante Fix: Wikileaks and Transparency .....................................491

A. Vigilante Transparency as Rights Protector and Enforcer ..................493

B. The Limits of the Vigilante Fix...................................................498

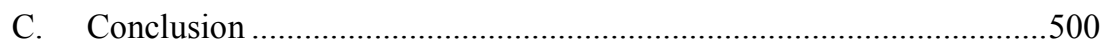

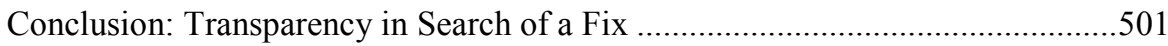




\section{INTRODUCTION: THE INFORMATION ASYMMETRY PROBLEM}

Government transparency does not spring naturally from the modern democratic state. As Max Weber maintained, "[b]ureaucratic administration always tends to exclude the public, to hide its knowledge and action from criticism as well as it can." The prerogative to create and maintain information asymmetries is one that government entities and officials do not easily surrender. ${ }^{2}$ Open government laws, which create legally enforceable rules requiring government entities to make information available, are thus largely the consequence of concentrated political activism and advocacy. For more than five decades, a broad transparency advocacy movement, composed of a diverse array of organizations operating from the transnational to local level, has attempted to address and mitigate the fundamental democratic and administrative problems that information asymmetry creates for legitimate and effective governance. ${ }^{3}$

At its inception, the movement understood and defined excessive state secrecy as a problem caused by a scarcity of laws—one that could be solved by a powerful, wide-ranging, and publicly enforceable legal right to government information. The quintessential campaign, which had historical antecedents and contemporaries in the United States and elsewhere, ${ }^{4}$ was the mid-twentieth century effort in the United States that resulted in enactment of the federal Freedom of

\footnotetext{
${ }^{1} 3$ Max Weber, Economy And Society: An Outline OF InTERPREtive Sociology 992 (Guenther Roth \& Claus Wittich eds., 1968).

${ }^{2}$ See id. at 992-93 (identifying the bureaucracy's "pure power interest" in protecting its secrets from the legislature, something it will defend "fanatically").

${ }^{3}$ For a summary of the claims made about secrecy's costs to legitimate and effective governance, see Mark Fenster, The Opacity of Transparency, 91 IowA L. REV. 885, 895-902 (2006).

${ }^{4}$ The most important domestic predecessor is discussed infra Part I-A. If one views transparency advocacy as a subset of more general campaigns for good government, then it dates back at least to the Progressive Era, when a social and political movement led the charge for reforms to eradicate bureaucratic corruption, especially at the municipal level. See ROBERT H. WIEBE, THE SEARCH FOR ORDER: 1877-1920, at 164-85 (1967). Indeed, Louis Brandeis' famous claim that sunlight is "the best of disinfectants," made as part of his campaign as a progressive trustbuster, dates from this period. LouIS D. Brandeis, Other People's Money and How the Bankers Use It 92 (Augustus M. Kelley Publishers 1986) (1914). With respect to international precedents, Anders Chydenius, a priest and legislator, led Sweden to adopt the first freedom of information law in 1766. See Juha Manninen, Anders Chydenius and the Origins of World's First Freedom of Information Act, in THE WORLD's FIRST FREEDOM OF INFORMATION ACT: ANDERS ChydENIUS' LEGACY TODAY 18 (Juha Mustonen ed., 2006). But the Swedish law was limited to the press and did not establish a public right to information; nor did it augur a significantly more open domestic state or inspire imitation in the manner of the U.S. FOIA. See Leena Luhtanen, Transparency at the Core of Democracy, in THE WORLD's FIRST FrEedom OF INFORMATION ACT: ANDERS CHYDENIUS' LegACY TODAY, supra, at 56; Manninen, supra, at 52-53.
} 
Information Act in 1966. ${ }^{5}$ That campaign has never ended. Numerous contemporary domestic and international non-governmental organizations (NGOs) endeavor to preserve, strengthen, and extend open government mandates. ${ }^{6}$

But the results of the freedom of information (FOI) campaign's labors, while considerable, have not fully solved the problem that it sought to address, at least for the many advocates in the U.S. and around the world who regularly complain about the laws' limited scope and their inadequate enforcement. ${ }^{7}$ In recent decades, several new networks and groups have responded to these frustrations by advocating alternative means to open the state to public view. Law, their efforts imply, is not the answer to secrecy, or at least not the only solution.

I discuss three such campaigns in this article. The anti-corruption movement, exemplified by the NGO Transparency International, views transnational and domestic activism - which includes both lobbying for freedom of information laws and gathering and distributing information about governmental performance-as essential weapons in the larger battle to identify and stigmatize venal states and unscrupulous officials. ${ }^{8}$ This movement insists that transnational NGOs can use the

\footnotetext{
${ }^{5}$ Freedom of Information Act, 5 U.S.C. § 552 (2006) (FOIA).

6 Organizations that campaign on behalf of freedom-of-information laws include OpenTheGovernment.org, a coalition of organizations devoted to "stimulating legislative and executive branch action and garnering media attention to the benefits of government openness," We Do, OPENTHEGOVERNMENT.ORG, http://www.openthegovernment.org/we_do (last visited July 7, 2012 ), the National Freedom of Information Coalition, which "protects our right to open government," especially at the state level, About NFOIC, NAT'L FREEDOM OF INFO. COALITION, http://www.nfoic.org/aboutnfoic (last visited July 7, 2011), and OMB Watch, which "exists to increase government transparency and accountability; to ensure sound, equitable regulatory and budgetary processes and policies; and to protect and promote active citizen participation in our democracy," About Us, OMB WATCH (July 28, 2011), http://www.ombwatch.org/about_us. Internationally, the human rights organization Article 19 defends and promotes freedom of expression and freedom of information all over the world and especially promotes "international human rights standards and ... legislation that protects the right to speak and right to know in countries emerging from conflict, war and genocide or repression." Who We Are, ARTICLE 19, http://www.article19.org/pages/en/who-we-are.html (last visited July 7, 2012). The website freedominfo.org, which is funded by several foundations and works with the National Security Archive in the U.S., serves as a "virtual network" for the many national FOI movements that have emerged in the last few decades, and provides "crucial information on freedom of information laws and how they were drafted and implemented, including how various provisions have worked in practice." About Us, FREEDOMINFO.ORG, http://www.freedominfo.org/about-us/ (last visited Nov. 7, 2011). For general descriptions of the international FOI advocacy movement, see ALASDAIR ROBERTS, BLACKED Out: GovernMENT SECRECY IN THE INFORMATION AgE 107-11 (2006); John M. Ackerman \& Irma E. Sandoval-Ballesteros, The Global Explosion of Freedom of Information Laws, 58 ADMIN. L. REV. 85, 121-23 (2006).

${ }^{7}$ See infra notes $87-89$ and accompanying text.

${ }^{8}$ See infra Part II.
} 
information they obtain from and about the state to lobby, pressure, and shame government into operating more accountably. ${ }^{9}$ Second, the "digital transparency" movement champions the use of information technology and networked communication as the solution to government secrecy, as well as a medium that can create a more participatory, collaborative state. ${ }^{10}$ For its advocates, technology will open the state by freeing its data. ${ }^{11}$ Third, WikiLeaks claims that its technological ability to distribute liberated (or stolen) government documents over the Internet will usher in a newly transparent state. ${ }^{12}$ This organization views itself as enforcing the public's natural and internationally recognized human right to government information through extralegal means, assisted by arguably illegal acts - and often ones that are clearly illegal. ${ }^{13}$ These four campaigns-FOI, anti-corruption, digital transparency, and WikiLeaks - share a commitment to the nearly religious, normative concept of transparency around which they are organized, ${ }^{14}$ while each focuses on different issues and offers a distinct set of policy prescriptions. "Transparency" is a goal, a happy ending that inspires very different policy stories.

This article probes the continuities and discontinuities among these movements and in the stories they tell. ${ }^{15}$ My purpose is two-fold. First, I explain that each of these movements operates privately - that is, as an activist advocating from outside of the state $^{16}$ - in search of a means to fix what it views as a

${ }^{9} I d$.

${ }^{10}$ See infra Part III.

${ }^{11} I d$.

${ }^{12}$ See infra Part IV.

${ }^{13} I d$.

${ }^{14}$ See Christopher Hood, Transparency in Historical Perspective, in Transparency: The Key to Better Governance? 3, 3-5 (Christopher Hood \& David Heald eds., 2006) (noting the abstract nature of transparency as a concept, as well as its "quasi-religious significance" and its ongoing evolution).

15 There can be no doubt about transparency's ascendance as a concept among academic advocates, especially in the economic and legal academic literature. See Emiliano Grossman et al., Economies Through Transparency, in TRANSPARENCY IN A NEW GlOBAL ORDER: UnVEILING ORganiZATIONAL VISIONS 97, 100-01 (Christina Garsten \& Monica Lindh de Montoya eds., 2008) (displaying a chart that shows an extraordinary rise in use of the term in journals within the EconLit database between 1986 and 2004, and especially between 1997-2004); Guy I. Seidman, Lawyers are from Mars, Political Scientists are from Venus: Who Gets Transparency Right? (Mar. 21, 2011) (unpublished manuscript) (on file with author) (finding in search of law review publications between 1990 and 2010 a nearly forty-fold increase in the use of the term "transparency" and a nearly three-fold increase in the use of the term "freedom of information").

16 They are all led by NGOs and funded by a mix of civic-minded interest groups, charitable foundations, and like-minded individuals. Among the leading foundations that support work on 
fundamental and pervasive problem endemic to government. They share assumptions about the needs and rights of democratic citizens to have access to government information in order to mitigate - or, better, eradicate - the asymmetric informational advantage the state enjoys over its public. But they diverge significantly in how they understand not only the problem's causes but also the state itself. In extolling the virtues of its own particular fix, each campaign offers a broader vision of transparency's mission, one tied to its particular understanding of the current state and of the better state that it hopes will emerge under the administrative conditions that its work will surely help create. The transparency fix - an idea that occupies a pivotal position in contemporary debates about governance, administration, and regulation-thus reveals our political and social anxieties about administration and about how we understand and attempt to correct the shortcomings of administrative law.

Second, the article unveils transparency as a contested political issue that masquerades as an administrative tool. The existing literature advocating and developing transparency as a concept has failed to map out transparency as a diverse and contested political field; instead, it has assumed transparency's status

transparency are the Open Society Foundations, which sponsor a "Transparency and Integrity Fund" to increase access to information at the U.S. state and federal levels and provide support for individual projects throughout the world. See About the Transparency and Integrity Fund, OPEN SOC'Y FOUNDS., $\mathrm{http} / / /$ www.soros.org /about (last visited July 7, 2012) (announcing availability of funding "for a wide range of policy advocacy strategies" relating to transparency); Fiscal Decentralization Initiative, Loc. GOV’T \& PUB. SERVICE REFORM INITIATIVE, http://gi.osi.hu/documents.php?m_id=191 (Feb. 18, 2009) (subsidiary of Open Society Institute); Rising Voices Launches Technology for Transparency Network, OPEN SOC'Y FOUNDS., http://www.soros.org/initiatives/information/focus/communication/news/ transparency-tools-20100119 (Jan. 19, 2010) (announcing a program co-created by Open Society Foundations grantee to promote the "use of technology for transparency and accountability" throughout Latin America, Asia, and Africa, among other places). Other foundations that have funded or established transparency-related projects include the Carnegie Corporation of New York and the Ford Foundation. See Carnegie Results: Spring 2010, CARNEGIE CORP. OF N.Y., http://carnegie.org/fileadmin/Media/ Publications/carnegie_results_spring_10_final_02.pdf (Spring 2010) (highlighting Carnegie's support for the Project on Government Oversight, a "nonprofit organization that works with whistle-blowers to add transparency to government operations"); Democratic and Accountable Government: Promoting Transparent, Effective and Accountable Government, FORD FOUND., http://www.fordfoundation.org/ issues/democratic-and-accountable-government/promoting-transparent-effective-and-accountablegovernment (last visited July 7, 2012) (announcing support for "community-driven efforts to improve the transparency and integrity of government institutions and processes"). Indeed, the problems that WikiLeaks has faced in receiving private donations-beginning in late 2010, major credit card companies, payment processors, and the owners of other payment systems stopped enabling individuals to send money to WikiLeaks - illustrate the extent to which NGOs must rely upon fundraising from private sources. On WikiLeaks's financial struggles, see Yochai Benkler, A Free Irresponsible Press: WikiLeaks and the Battle Over the Soul of the Networked Fourth Estate, 46 HARV. C.R.-C.L. L. REV. 311, 341-43 (2011). 
U N I V E R S I T Y O F P I T T S B U R G H L A W R E V I E W

PAGE

as a universal norm and debated the technical and legal issues of optimal administration and application. ${ }^{17}$ But as I demonstrate, each transparency campaign's competing fix and vision of a more perfect, visible state rests on contested claims about the state's legitimacy and performance, and competing theories of law, policy, and the state. That is, each movement and its fix implicate "transparency" in a much broader set of normative commitments. To understand transparency as an historically contingent concept and administrative norm, one must understand the political and social world within which it is defined by the networks, groups, and individuals who attempt to pressure the state to adopt their vision of visible, accountable governance. Viewed in context rather than simply as a transcendent normative goal or neutral technical tool, transparency emerges as a political concept that is deployed in diverse campaigns as a part of broader political and economic projects.

Part I begins by introducing the legal-based and rights-based understanding of transparency that developed in the mid-twentieth century U.S. It describes that campaign's two distinct stages: First, as World War II was winding down, newspaper editors' trade groups sought to export free speech ideals and the model of an objective and independent press abroad to the new world that the post-war period seemed to herald. Later, those trade groups shifted their attention to what they saw as the growing problem of domestic state secrecy. This second period adapted the legalistic concepts of press freedom and rights that had been developed in the earlier period as a "right to know" and the "freedom of information" for the somewhat different project of advocating laws to require the U.S. government to disclose information to the public. Parts II through IV describe three contemporary movements that attempt to extend the transparency ideals in the U.S. and internationally: the transnational campaign to fight corruption (Part II); the effort to remake the state and its relationship to the public in a digital, networked world (Part III); and, in the WikiLeaks organization, the vigilante struggle to impose an

\footnotetext{
${ }^{17}$ In earlier work, I have reviewed the normative and consequential literature on transparency, which focuses on its democratic and administrative benefits and costs; this large body of work considers what transparency does, not the political conditions under which transparency is adopted. See Fenster, supra note 3, at 894-910. Works that offer normative arguments in transparency's favor provide brief accounts of the FOI movement and of more recent efforts to advocate transparency, but they generally provide little historical, political, and social context. See, e.g., ARChON Fung, MARY Graham \& DAVID WeIL, Full Disclosure: The Perils and Promise of Transparency 24-29 (2007) (describing "The Struggle Toward Openness" and "A Slow March Toward Right-to-Know" before shifting to the history of disclosure-based regulation); SuZanne J. Piotrowski, Governmental Transparency in the PATH OF ADMINISTRATIVE REFORM 21-24 (2007) (providing an "overview and history of the federal FOIA" in a study of the relationship between open government and the new governance or new public management movement).
} 
ethic of transparency on a recalcitrant state (Part IV). The conclusions to Parts II through IV provide a comparative perspective on the different campaigns, noting their continuities and discontinuities, and the Conclusion summarizes what this study reveals about transparency and the longing for a fix to the information asymmetry problem the state creates. ${ }^{18}$

\section{The Legal Rights Fix: FOIA AND THE ORIGINS OF THE "RIGHT TO KNOW" AND "FREEDOM OF INFORMATION"}

In the decades following World War I and especially in the latter years of World War II, leading newspaper editors and press associations actively worked to export abroad the American model of a private, for-profit press insulated from government oversight and censorship. Frequently referred to as a plan to promote the "freedom of information" and the public's "right to know," the campaign rehearsed the ideas that would culminate decades later in the Freedom of Information Act (FOIA). In addition to advocating in favor of public access to government information as one among many issues, the campaign helped sharpen the arguments in favor of limiting state secrecy, and it established the press' ability to collaborate with government entities to achieve that goal. The initial transparency advocacy movement eventually enjoyed legislative success and laid both the conceptual and organizational groundwork for what has become an international network of institutions advocating on behalf of transparency.

\section{A. Exporting Rights and Freedoms}

The initial campaign began as a response to two related issues: concerns about the availability of foreign markets for American newsgathering and distribution and a desire to export American free press and liberal democratic ideals. The American press and especially the American wire services-which supplied national and international news to many local newspapers and thus, at the time, were the country's most global and national media firms-faced journalistic and economic constraints in attempting both to collect news in other countries and to export their products around the world. In the mid-nineteenth century, a cartel of major European news agencies, which included Reuters (Great Britain), Agence Havas (France), and Wolff (Germany) as its original members, had divided the world among themselves for purposes of newsgathering. They agreed both to geographic

\footnotetext{
${ }^{18}$ My focus here is largely on efforts to address executive branch and administrative secrecy, but it can apply to campaigns focused on congressional secrecy. See, e.g., Jane S. Schacter, Digitally Democratizing Congress? Technology and Political Accountability, 89 B.U. L. REV. 641, 648-62 (2009) (describing efforts to use the Internet to impose transparency on Congress).
} 
constraints limiting themselves to their demarcated territories and to publish international news only from the cartel's members. ${ }^{19}$ The American Associated Press (AP) was invited to join the cartel in 1887 and enjoyed the competitive advantages it provided for several decades. ${ }^{20}$ The AP did not find its participation entirely satisfactory, however. As the U.S. newspaper industry and the domestic market for news grew, the cartel's constraints on the AP's newsgathering operations abroad bridled the expanding company. The AP faced tougher domestic competition from the United Press (UP) (founded in 1907), which was unconstrained by the cartel agreement. ${ }^{21}$ At the same time, the AP had started its own newsgathering information in far-flung territories, first in South America and then around the world. ${ }^{22}$

The AP was also concerned about the cartel's effects on news content. The European agencies had formal and informal ties to national governments that sought to shape news for propagandistic ends. As a result, the AP complained, foreign media frequently under-reported news from the United States and described the country in an uncomplimentary fashion. ${ }^{23}$ For the American press, this potent and dangerous mix of troubling practices - individual wire services that had close relationships with their own governments, a cartel with oligopolistic control over international news distribution, and the lack of the objective news values that American news editors increasingly prized - endangered the press and nation's political and economic interests. ${ }^{24}$

These conditions prompted news organizations - as both interested parties and upholders of emergent ideals for a free press - to help develop entrepreneurial, independent news media around the world. In the narrative that Cold War

\footnotetext{
${ }^{19}$ Terhi Rantanen, The Struggle for Control of Domestic News Markets (1), in The GLoBalization OF News 35, 36-37 (Oliver Boyd-Barrett \& Terhi Rantanen eds., 1998).

${ }^{20}$ Terhi Rantanen, Foreign Dependence and Domestic Monopoly: The European News Cartel and U.S. Associated Presses, 1861-1932, 12 MEDIA HIst. 19, 26-27 (2006) [hereinafter Rantanen, Foreign Dependence].

${ }^{21}$ Margaret Blanchard, EXPORTING THE First AMENDMENT 6-7 (1986).

${ }^{22}$ Rantanen, Foreign Dependence, supra note 20, at 28-30. Indeed, the UP also directly competed with the cartel itself, leading the cartel finally to grant AP full membership in order to compete more effectively with UP's challenge. Terhi Rantanen, Mr. Howard Goes to South America: The United Press Associations and Foreign Expansion, ROY W. HOWARD MONOGRAPHS IN JOURNALISM AND MASS CoMm. Res., May 15, 1992, at 22-24.

${ }^{23}$ BLANCHARD, supra note 21, at 7; KENT COOPER, BARRIERs DOwn 43 (1942).

${ }^{24}$ Oliver Boyd-Barrett, The International News Agencies 209-11 (1980); CoOPer, supra note 23 , at $43-44$.
} 
advocates constructed to tell the story about the necessity for informational freedom and rights, ${ }^{25}$ the AP's commercial triumph, in which the agency and its powerful general manager Kent Cooper broke free from and helped smash the global news cartel in 1934, was not merely a self-serving effort to expand the company's commercial reach. It also accompanied a full-fledged campaign to promote democracy. ${ }^{26}$ The cartel's demise, coupled with the havoc wreaked on German and French news production by the Nazi party's ascent and Germany's subsequent occupation of France in World War II, allowed American corporate entities to seize market share and gain influence through the distribution of news and propaganda to Western Europe and developing countries in the post-war period. ${ }^{27}$ Once the cartel was broken, Cooper proclaimed, no more would such a "perfect instrument that could covertly, effectively and without the suspicion of the uninitiated carry on the great game of international government propaganda." 28 Indeed, as the AP and UP began to coordinate as well as compete, the U.S. emerged in the post-war period as the only nation with multiple news services, helping it to take a leading position in the global competition over news and media content. ${ }^{29}$ The American press' triumphant effort to advance what it viewed as the

${ }^{25}$ On the relationship between ideals of the "free flow of information" and the Cold War, see Hanno Hardt, Comparative Media Research: The World According to America, 5 CRITICAL STUD. MASS Сомм. 129, 132-33 (1988).

26 Graham StORey, Reuters' Century, 1851-1951, at 186-94 (1951); Herbert Brucker, FREEDOM OF INFORMATION 214-15 (1949). Significantly, Cooper gave his memoir of the AP's fight against the cartel, published in the midst of World War II, the martial title Barriers Down. Cooper's story was self-serving and not entirely true; the AP, in fact, had a more complex, often friendly relationship with the government-controlled members of the international press cartel, and its efforts were as much in response to competition from the United Press as for a broader ideological or nationalistic purpose. See Terhi Rantanen, After Five O’Clock Friends: Kent CoOPER AND Roy W. HOWARD 25-27 (1998).

${ }^{27}$ One can view this critically, as a form of cultural imperialism, see, for example, HERBERT SCHILLER, Mass COMmunications AND AMERICAN EMPIRE 24-45 (1969); Altaf Gauhar, Free Flow of Information: Myths and Shibboleths, 1 THIRD WORLD Q. 53, 53-54 (1979), or as a means to lower barriers that stopped content and commerce from flowing freely among nations for ideological and commercial reasons, see for example Erwin D. Canham, International Freedom of Information, 14 LAW \& CONTEMP. PROBS. 584, 584-85 (1949).

${ }^{28}$ Kent COOPER, The Right to KNOW 154 (1956).

29 Daniel R. Headrick, The InVisible Weapon: Telecommunications and International Politics 1851-1945, at 189-90 (1991); EMILY S. ROSENBERG, WORLD WAR I AND THE GROWTH OF United States PREDOMinANCE IN LATIN AMERICA 187 (1987). 
free markets it needed to thrive was ideological as well as profitable, ${ }^{30}$ a fact occasionally remarked upon by European skeptics. ${ }^{31}$

Having defeated its competitors abroad, the American press turned evangelical. In its 1944 convention, the American Society of Newspaper Editors (ASNE), the most active trade group representing news editors and journalists, announced a campaign to protect "the right of the people" against censorship and to advocate for "freedom of information" around the world. ${ }^{32}$ The campaign included a world tour undertaken (with the assistance of the State Department) by three editors during the waning days of the war to review the state of the press in other

${ }^{30}$ See, e.g., Kent Cooper, Newspaper Statesmanship for Peace, in JouRNALISM IN WARTIME 214, $215-$ 16 (Frank Luther Mott ed., 1943) (noting, in a short article exhorting the press to exert itself in peace negotiations because of the importance of a free press and informed public to ending wars, the relationship between wars and the prosperity of the international news industry).

${ }^{31}$ In the most public such episode, the British magazine, the Economist, viewed Cooper's aggressive efforts to expand the AP as an independent source of news throughout the world quite skeptically, complaining that he

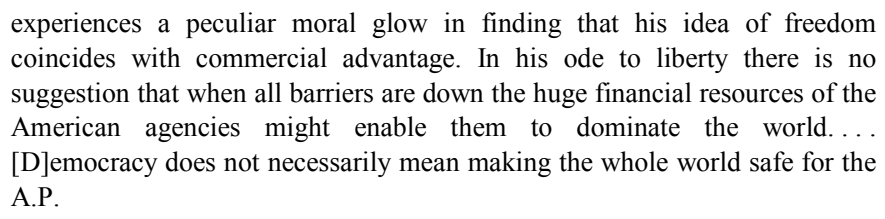

The Press: Storm Warning, TIME (Dec. 11, 1944), http://www.time.com/time/magazine/article/ $0,9171,883902,00 . \mathrm{html}$ (quoting the Economist). In a response published in Time, Cooper suggested that perhaps the Economist wanted the British to control world communications. Id. Five years later, in his book Freedom of Information, Herbert Brucker explicitly defended the confluence of free press and enterprise and asked, "Suppose there is opportunity for commercial gain in striking down the barriers that block nation off from nation-is it not still a good idea?" BRUCKER, supra note 26, at 215. Whether a "good idea" or not, Cooper sought to do more than simply counter foreign propaganda with the products and viewpoints of the American press; the AP's work preeminently served the commercial interests of American media industries that exported their news reporting abroad via their wire services and to open those markets to American reporters-all as part of American companies' efforts to compete against the press services of other nations. For a general description of the incident and of the ongoing tensions between American and European diplomats and press representatives in the post-war negotiations about United Nations freedom of information agreements, see BLANCHARD, supra note 21, at $23-25$.

${ }^{32}$ George Kennedy, Advocates of Openness: The Freedom of Information Movement (Aug. 1978) (unpublished Ph.D. dissertation, University of Missouri at Columbia) (on file with author). Cooper himself called for such a campaign that same year in the pages of Life. See Kent Cooper, Freedom of Information: Head of Associated Press Calls for Unhampered Flow of World News, LiFE, Nov. 13, 1944 , at 55 . 
nations, ${ }^{33}$ lobbying efforts on behalf of international rights for a free press in the new United Nations, ${ }^{34}$ and collaboration with the Truman administration to spur development of an international press industry that would adopt the American model of the profession. ${ }^{35}$ Press representatives ultimately played key roles in the Sub-commission on Freedom of Information created by the UN's Human Rights Commission in 1947 and, alongside prominent Harvard constitutional law professor Zechariah Chafee, served as delegates to the Conference on Freedom of Information held in Geneva in $1948 .^{36}$

In a 1949 article, Erwin Canham, editor of the Christian Science Monitor, officer of the American Society of News Editors, and member of the American delegation in Geneva, ${ }^{37}$ surveyed journalistic practices around the world and ranked them against the preeminent work of the American media in supporting the American democratic model. None quite matched up, although Canada and Britain came close. Therefore, Canham argued, the U.S. must spearhead the effort to free the flow of information throughout the world and thereby expand political freedom and fight the growing threat of authoritarianism:

Of course, despotisms of various degrees will finally end when the people really know what is happening to them-when they learn the facts of international and national life - and thus throw off their chains. Freer information, in the broadest sense, will ultimately bring tyranny down. And so the efforts to lower barriers will ultimately produce conditions that will bring about a truly free press everywhere. $^{38}$

The specter of "tyranny" he identified meant the Soviet Union, of course, the principal Cold War threat. Alongside many of his fellow prominent newspaper editors, Canham played a semi-official role in the United States' effort to spread its vision of a liberal democracy abroad. For Canham and his colleagues, the ideal

\footnotetext{
${ }^{33}$ See Alice Fox Pitts, Read All About It! 50 Years of ASNE 174-81 (1974). The tour was led by led by Ralph McGill, an editor for the Atlanta Journal-Constitution and chairman of the ASNE's Freedom of Information Committee. See Leonard Ray Teel, The Shaping of a Southern Opinion Leader: Ralph McGill and Freedom of Information, 5 AM. JOURNALISM 14, 14-27 (1988).

${ }^{34}$ BLANCHARD, supra note 21, at 52-89; PITTS, supra note 33, at 182-85.

${ }^{35}$ BLANCHARD, supra note 21 , at 2.

${ }^{36}$ Id. at $155-63,174-97$.

${ }^{37} \mathrm{Id}$. at $174-75$.

${ }^{38}$ Canham, supra note 27, at 589 (A typographical error in original source was corrected here.).
} 
press was private, independent, and capable of objectively reporting on events, and enjoyed and helped enforce liberal democratic rights. The press under an authoritarian government, by contrast, served as the state's mouthpiece, a propaganda organ rather than a true Fourth Estate. A truly free press, therefore, required not only a private, independent set of media institutions but also a limited, non-intrusive state. It was up to the U.S. and its press institutions to spread the word. $^{39}$

Ironically, this project-intended to promote the ideals of a free pressrequired underwriting by the very government whose clutches journalists feared. The midcentury American press viewed the federal government's intervention in the marketplace of ideas and news as a significant, authoritarian-like threat to American democracy. ${ }^{40}$ During World War I and its aftermath, the government had not only acted as an official censor, a traditional role for the state during wartime, but also as a major producer of informational content akin to propaganda. ${ }^{41}$ The government's post-war informational activities now included pushing material to the public in order to grab the attention and shape the attitudes of its citizens, like the growing consumer-goods industries that utilized press agents and advertisers to push their interests and hawk their wares. ${ }^{42}$ For the editors who sought its support

${ }^{39}$ During the Cold War, scholars and journalists noted that different approaches to press freedoms existed, that nation states generally adopted one of them and disdained the others, and that the underlying theory justifying each approach rested on the political theory underlying each nation's regime. The American model was decidedly "libertarian" or classically liberal, and contrasted with the authoritarian, Soviet communist (which scholars differentiated from the authoritarian model) and socialdemocratic, "social responsibility" models. See generally Fred S. Siebert, THEOdORE Peterson \& Wilbur Schramm, Four Theories of the Press (1956); see also William E. Berry et aL., Last Rights: REvisiting Four THEORIES OF THE PRESS 7-16 (John C. Nerone ed., 1995) (historicizing and updating the "Four Theories" model).

${ }^{40}$ COOPER, supra note 28 , at $64,95-96,147-48$; BRUCKER, supra note 26 , at 221 . This conflict arose not only from the importance the press placed on its independence from the state. Newspaper publishers tended to be quite conservative and disliked President Roosevelt, the Democratic Party, and the New Deal. See BLANCHARD, supra note 21, at 2.

${ }^{41}$ COOPER, supra note 28 , at 163-65.

${ }^{42}$ See id. at 308 (warning that a passive "American layman," allowing the state to "do[] his thinking for him," will allow the government to infringe his "Right to Know"). Cooper's concern about propaganda spread by government press agents was widely shared in the 1930s. See E. PEndLETON Herring, Public Administration AND the PUblic InTERest 362-67, 373-76 (1936) (describing the Roosevelt administration's increasing use of "public relations" professionals in its attempt to manage publicity and the press); Michael Schudson, Discovering THE News 134-44 (1978) (discussing generally the press' distaste for the public relations industry); see, e.g., JOHN DEWEY, INDIVIDUALISM OLD AND NEW 43 (1930) (characterizing the "publicity agent" as "the most significant symbol of our present social life"). 
in their international campaign, the state thus represented both a means to project press freedom ideals and a grave threat to the press' crucial role in reporting news objectively and thoroughly. ${ }^{43}$

In this sense, the movement to export First Amendment and journalistic values also reflected a strong professional identity among the press leaders who viewed the journalistic enterprise as free, independent, and objective, and staffed by full-time, well-trained, professional journalists. ${ }^{44}$ Journalistic objectivity in this context served as an American professional ideal and norm, and stood in opposition to political and ideological partisanship and to subjective or biased reporting. ${ }^{45}$ In journalism historian Michael Schudson's authoritative account, objectivity defines and disciplines journalism as a vocation: it binds publishers, reporters, and editors together through a series of rituals that define what journalism is and how it is produced; it allows constituents of the journalistic community to recognize and exclude those who fail to practice it correctly; and it organizes the bureaucratic

${ }^{43}$ State influence on the press and the public was not the press' only concern about government interference. During the New Deal, the Roosevelt administration had fought to impose against news organizations federal laws and regulations that applied to employers, including the Social Security Act, the National Industrial Recovery Act, federal labor laws, and the Wagner Labor Relations Act, as well as federal laws and regulations intended to regulate advertising. Claiming that these laws would infringe constitutional free speech rights if applied to the press - an argument that the press lost-newspapers and their owners, whose relative conservatism made them skeptical, if not hostile, to the New Deal anyway, resisted the state's intrusion into their business. Margaret A. Blanchard, The Hutchins Commission, The Press and the Responsibility Concept, Journalism MONOGRAPHS, May 1977, at 4-8. As the Supreme Court declared in Associated Press v. NLRB, 301 U.S. 103, 132 (1937), "[t]he publisher of a newspaper has no special immunity from the application of general laws."

${ }^{44}$ On the history of journalism's understanding of itself as a profession with a distinct and crucial social and political position and a self-developed and enforced code of conduct, see Howard Tumber \& Marina Prentoulis, Journalism and the Making of a Profession, in MAKIng Journalists 58, 60-68 (Hugo de Burgh ed., 2005). The Commission on Freedom of the Press, a private, widely heralded group of leading academics and government officials brought together under the leadership of Robert Hutchins, president of the University of Chicago at the time, declared in its 1947 final report that the press had the social and professional responsibility to provide "full access to the day's intelligence" and a "truthful, comprehensive, and intelligent account of the day's events in a context which gives them meaning." COMM'N ON FreEdom of THE PRess, A FreE AND ResPonsible Press 21, 28 (1947). On the Hutchins Commission generally, see Blanchard, supra note 43, at 88-89.

${ }^{45}$ Wolfgang Donsbach, Lapdogs, Watchdogs and Junkyard Dogs, 9 MEDIA STUD. J. 17 (1995); Gaye Tuchman, Objectivity as Strategic Ritual: An Examination of Newsmen's Notions of Objectivity, 77 AM. J. OF Soc. 660, 660-78 (1972). A foil that freedom-of-information advocates employed for purposes of defining objectivity were publications produced by and for particular private interest groups, especially the labor press supported by unions. See Leonard RAy TeEl, The Public Press, 1900-1945, at 17274 (2006); BRUCKER, supra note 26, at 248-51. 
U N I V E R S I T Y O F P I T T S B U R G H L A W R E V I E W

PAGE

practice of journalism and the training of those who wish to enter the profession. ${ }^{46}$ The objectivity ideal helps justify the press' explicit right to be free from government constraint, and it constitutes the pillar of the press' role as an independent institution of civil society - one just as important to the protection of individual rights and democratic institutions as an independent judiciary.

\section{B. The Right to Know and Freedom of Information, from Press Ideals to Legal Informational Rights}

All of the circumstances described above - the political economy of the international news industry, the AP's struggles with the European news cartel, the emergent ideal of press freedom during the gathering Cold War, and the press' selfconception of journalism as a vocation organized around the objective reporting of news - contributed to the historical context in which the phrases "freedom of information" and the "right to know" began to circulate. Kent Cooper used the phrase "right to know" as early as 1945 and as the title of his 1956 book on the general topic of press freedom. ${ }^{47} \mathrm{He}$ defined it both affirmatively, as the right of individuals to have access to full and accurate news reporting, and negatively, as prohibiting the government from interfering with the relationship between the press and its public. "It means," he wrote, "that the government may not, and the newspapers and broadcasters should not, by any method whatever, curb delivery of any information essential to the public welfare and enlightenment." $48 \mathrm{He}$ also offered a modern revision of the Constitution's First Amendment: “Congress shall make no law ... abridging the Right to Know through the oral or printed word or any other means of communicating ideas or intelligence." ${ }^{49}$ In Cooper's understanding, the right to information belongs to the public; the state has the legal duty to disclose and is prohibited from restraining the press; and the independent commercial press serves as the essential go-between with an ethical, as opposed to legal, duty to ferret out and present information. The press-which enjoys a longstanding and well-entrenched constitutional right-would protect the public's right by transforming data into knowledge and thereby allow the reading public to respond rationally and act politically, as capable democratic citizens.

${ }^{46}$ Michael Schudson, The Objectivity Norm in American Journalism, 2 JouRNALISM 149, 151-52, 16567 (2001).

${ }^{47}$ COOPER, supra note 28; The Right to Know, N.Y. TIMES, Jan. 23, 1945, at 18.

${ }^{48}$ COOPER, supra note 28 , at 16 .

${ }^{49} I d$. 
The term "freedom of information" had a similar meaning. President Franklin Delano Roosevelt used it in a press conference in 1940 to refer to the flow of uncensored news, identifying it as one of the key principles of democratic government and the un-enumerated freedoms that the Constitution set in motion, ${ }^{50}$ while President Truman used it similarly in a message to Congress in 1947 reporting on U.S. participation in the United Nations. ${ }^{51}$ At the same time, news editors viewed and deployed the phrase as part of the broad ideal of press freedom. The ASNE established a "Freedom of Information Committee" to push for international speech liberalization, and Herbert Brucker, one of that committee's chairmen during the early post-war period, appropriated the term as the title for his 1949 book on the need for press freedom. ${ }^{52}$ The nascent international human rights movement appropriated the phrase as well. In its first meeting in 1946, the United Nations General Assembly issued a declaration calling for recognizing and protecting the freedom of information as a fundamental, "touchstone" human right while defining it quite broadly: "Freedom of information implies the right to gather, transmit and publish news anywhere and everywhere without fetters.",53

${ }^{50}$ Cass Sunstein, The Second Bill of Rights: FDR's Unfinished Revolution And Why We NeEd It MoRe Than Ever 78-79 (2004). The phrase did not appear in FDR's "four freedoms" speech he made to Congress in 1941, which instead only referred to the "freedom of speech and expressioneverywhere in the world."

${ }^{51}$ See President Harry S. Truman, Message to the Congress Transmitting First Annual Report on U.S. Participation in the United Nations (Feb. 5, 1947), available at http://www.trumanlibrary.org/ publicpapers/index.php?pid=2225 (equating the concept with "action to break down the barriers to a wider, freer flow of information in the world"); see also Sanford J. Ungar, The Role of a Free Press Strengthening Democracy, in DEMOCRACY AND THE MASs Media 368, 393 (Judith Lichtenberg ed., 1990) (reporting Truman's use of the phrase in several speeches in 1947).

52 TeEL, supra note 45, at 17-18; BRUCKER, supra note 26; Kiyul Uhm, The Cold War Communication Crisis: The Right to Know Movement, 82 JouRnalism \& MASS COMM. Q. 131, 139 (2005). Brucker added a further meaning defining the term as a key element in the relationship between the press and its public: "freedom of information for newspapers and related media will have not only the historic sense of freedom from government but also include freedom from any attachment, direct or indirect, to any class, political party, economic group, or other fraction of society." BRUCKER, supra note 26, at 276. His definition suggested in its breadth (which went beyond the Bill of Rights' much simpler check on state power) the concern that the press must report news free from biases that would arise from "attachment" to anything besides the professional norms of objective reportage. Freedom of information was an institutional freedom for the press from external interference of any kind, including the state and private interests.

${ }^{53}$ G.A. Res. 59, U.N. Doc. A/RES/59(I) (Dec. 14, 1946), available at http://www.un.org/Docs/journal/ asp/ws.asp?m=A/Res/59(I). Two years later, a draft convention on Freedom of Information that failed to garner sufficient support defined the term as "the free interchange of information and opinions, both in the national and in the international sphere." BLANCHARD, supra note 21, at 410-14. Although Article 19 of the Universal Declaration of Human Rights adopted the general language of free expression and 
U N I V E R S I T Y O F P I T T S B U R G H L A W R E V I E W

PAGE

As concepts, the right to know and freedom of information overlap in a number of important ways and have endured as key phrases in the movement for open government. First, although they concern much more than simply government information, the concepts identified and sought to protect an international and national right that would limit the state's control of information flows. Second, they conceptualized the state as something distinct from the public - as an entity that represents and governs its citizens but is distant from them. The public must be protected from the state, while the state must be checked from violating private individuals' rights, which in this context meant the right to receive information and to "know." Third, the terms assume that information, in its raw and cooked forms as data, news stories, and opinion, constitutes a truth to which the public must have access in order to gain knowledge and act as citizens.

And finally, at least in its American version as defined by Cooper and Brucker, the terms contemplate a free and independent press as the public's agent in protecting the right to know and in delivering the information that should flow freely. Rights (to know) and freedoms (of information) simultaneously enable the press to report objectively, without the constraints of excessive state or private interest, and allow that independent pillar of society to play its crucial role in a functional democracy. As the institution capable of mediating between the public and a distant, increasingly complex state, the press had come by midcentury to view itself as the community's representative and enforcer of public rights, capable of unveiling and criticizing the state. ${ }^{54}$ "The right of the individual to know," Cooper asserted, is "coordinated with the right of his newspaper to tell him all the news, except what the government was guilty of withholding and suppressing." 55 The original FOI campaign's goals were to transform that inchoate notion of "guilt" into a legal wrong and to transform the abstract ideal of a "right" into an enforceable cause of action for the individuals to whom it belonged.

the right to receive and impart information, the more specific provisions considered in the 1948 Convention on Freedom of Information, which both protected individuals from the state and allowed states to support and protect their domestic press (for example, "in the interest of national safety" and to "develop its national news enterprises"), faced significant opposition, not least from the U.S. delegation. On the influence of the press on the U.S. delegation, see $i d$. at 174-75.

${ }^{54}$ James W. Carey, Journalism and Criticism: The Case of an Undeveloped Profession, 36 REV. OF PoL. 227, 231-33 (1974).

${ }^{55}$ COOPER, supra note 28, at 69. 


\section{The Political Enactment of Legal Informational Rights}

By the late 1940s, ASNE's Freedom of Information Committee, having been frustrated in its efforts to formalize press freedoms in international law, ${ }^{56}$ turned its attention to press freedom in the U.S. and to one particular issue: government secrecy. ${ }^{57}$ Louisville Courier-Journal editor James Pope's term as Committee chair, which started in 1950, proved integral to the organization's shift towards a political fight against federal, state, and local government secrecy and in making the fight against it explicitly political. Pope's committee began by organizing statelevel committees to help provide legal advocacy and defense on behalf of local newspapers, and to serve as the basis for an effort to change federal policy. ${ }^{58}$ Pope recruited Harold Cross, a retired media lawyer and journalism professor at Columbia, to serve as the Committee's legal advisor. ${ }^{59}$ In this capacity, Cross produced The People's Right to Know (1953), a book that both summarized the patchwork of existing constitutional and administrative laws regulating government secrecy and advocated for reforms to strengthen the public's access to information. ${ }^{60}$

As Pope noted in his foreword to Cross' book, ASNE stood alongside Cross as an "agent of the people" to enforce the people's right of access to information on the public's behalf. ${ }^{61}$ In that role, Cross declared that the press would strike down "the barriers to access to public records and proceedings," ${ }^{62}$ which was especially necessary, Pope noted, because citizens required assistance to understand an "increasingly complex government." rights concept from the press' earlier advocacy of press freedoms abroad and

\footnotetext{
${ }^{56}$ See supra note 53. more publicly exorcised about post-war secrecy.

${ }^{58} \mathrm{Uhm}$, supra note 52, at 136-37.

${ }^{59}$ Id. at $134-38$.

${ }^{60}$ Harold Cross, The People's Right to KnOw (1953).

${ }^{61}$ James S. Pope, Foreword to CROSS, supra note 60, at vii.

${ }^{62}$ CROSs, supra note 60, at xiv.

${ }^{63}$ Pope, supra note 61 , at ix.
}

${ }^{57}$ David R. Davies, The Postwar DeCline OF American NewsPapers, 1945-1965, at 31-38 (2006); HERbert N. Foerstel, FreEdom OF INFORMATION AND THE Right to KNOW 14-18 (1999); Kennedy, supra note 32, at 24-28; PITTS, supra note 33, at 172-73. While some press advocates complained about government censorship during the war, see, e.g., Erwin D. Canham, The Battle for News, in JOURNALISM IN WARTIME, supra note 30, at 44 (complaining about censorship, though conceding that censorship in the U.S. during World War II was less onerous than in other countries), the press grew 
framed the problem of secrecy as one of insufficiently enforced legal rights. The book opened with the most prominent terms from the earlier free press campaign:

Public business is the public's business. The people have the right to know. Freedom of information is their just heritage. Without that the citizens of a democracy have but changed their kings. ${ }^{64}$

"Rights" against the state, along with the ideal of "freedom" from state barriers to access, served as the logical way for a legal advocate like Cross to champion transparency. But the prevailing law of access to government information, Cross complained, was a mess; it existed only "where you find it," in a "welter of varying statutes, conflicting court opinions and wordy departmental regulations [that] present the problem as a veritable Chinese puzzle." ${ }^{, 55}$ The resulting information-access law could not confront and control the expansion of Cold War secrecy. Quoting a recent student-authored law review publication, Cross lamented the fact that access to information was "a neglected constitutional right," $" 66$ and argued that it ought to be encompassed within First Amendment protections. To that end, he cited a range of historical and contemporary figures for support. ${ }^{67}$ His efforts to find a constitutional basis for the "right to know" have proved unavailing, however, as the U.S. Supreme Court has never acknowledged such a broad right to informational access in the Bill of Rights. Nevertheless,

${ }^{64}$ CROSS, supra note 60, at xiii. Other books from the mid-1950s by prominent editors and activists in the older international free press movement employed the term "right to know" as including the right of access to information. COOPER, supra note 28, at 283-88; JAMES RUSSELL WigGINS, FREEDOM OR SECRECY 3-4 (1956). Following Cross, Wiggins-himself a former ASNE FOI Committee chairadvocated establishing an enforceable right to know. Id. at 71. On Wiggins, see Uhm, supra note 52, at $138-39$.

${ }^{65}$ CROSS, supra note 60, at 4, 6, 10 .

${ }^{66}$ Note, Access to Official Information: A Neglected Constitutional Right, 27 IND. L.J. 209 (1952) (relying largely on state court decisions and the statements of figures like James Madison and Thomas Cooley to support its argument).

${ }^{67}$ Cross, supra note 60, at 129-32. Zechariah Chafee's 1947 treatise Government and Mass Communications noted the problem of expanded secrecy in the post-war era but did not develop the First Amendment argument that Cross would later pursue. 1 ZeChariah Chafee, JR., Government AND Mass COMMUNiCATIONS: A REPORT FROM THE COMMISSION ON FREEDOM OF THE PRESS 12-13 (1947). In Free Speech and Its Relation to Self-Government (1948), Alexander Meiklejohn included the claim that the democratic values inherent in the First Amendment must allow the public access to information, but he never specifically considers the relevance and problem of state information. Alexander Meiklejohn, Free Speech and Its Relations to Self-Government 26, 66, 89 (1948). 
academics and advocates, most prominently First Amendment scholar Thomas Emerson, have repeated Cross' argument in the decades that followed. ${ }^{68}$

As an alternative, Cross offered federal legislation as a second-best path to legal rights. The Administrative Procedure Act, enacted in 1946, provided both a model of statutory control over administrative agency operations and a potential home for a freedom of information act. But it would require amendment, as its existing information-access provisions were too vague and riddled with exceptions; it also failed to create an enforceable public right to information that would allow an aggrieved citizen (whether or not a member of the press) to seek judicial review of a government entity's refusal to disclose information. ${ }^{69}$ To bridge this substantive and procedural gap, Cross urged Congress to "begin exercising effectually its function to legislate freedom of information for itself, the public, and the press" by creating a legal right to know. ${ }^{70}$ Cross' argument certainly convinced his ASNE sponsors; "[e]nlisted as an adviser," James Pope wrote, "he became our leader." $" 71$

Soon after the publication of Cross' book in 1953, the ASNE Committee finally found a potentially effective political government actor and partner for establishing the legal rights that Cross described. In November 1954, a new Democratic majority wrestled control of the U.S. House of Representatives back from a small Republican majority that had ridden Dwight Eisenhower's coattails in his 1952 election to a first presidential term. Although Eisenhower's moderate

\footnotetext{
${ }^{68}$ Thomas I. Emerson, Legal Foundations of the Right to Know, 1976 WASH. U. L.Q. 1, 1-24 (1976). A more recent legal academic advocate of the constitutional basis for an access right is Heidi Kitrosser, who, like Cross and Emerson, has argued that access rights are a subset of free speech rights, whose purpose is to enable democratic self-government and check government abuses. See Heidi Kitrosser, Secrecy in the Immigration Courts and Beyond: Considering the Right To Know in the Administrative State, 39 HARV. C.R.-C.L. L. REV. 95, 125-45 (2004). For more wide-ranging summaries of the human rights-based arguments in favor of a right to information, see Ackerman \& Sandoval-Ballesteros, supra note 6, at 88-93, and Roy Peled \& Yoram Rabin, The Constitutional Right to Information, 42 CoLuM. HuM. RTS. L. REV. 357, 359-73 (2011).

${ }^{69}$ CROSS, supra note 60, at 223-25. The APA's original government information provision included exceptions for information involved in "any function of the United States requiring secrecy in the public interest" and allowed information not otherwise barred from disclosure by statute to be made available by published rule "to persons properly and directly concerned except information held confidential for good cause found." Id. at 226 (quoting 5 U.S.C.A. § 1002(1), 1002(c) (1946)). In addition to analyzing the APA's weaknesses, Cross's book also listed all of the existing statutory exceptions from disclosure. Id. at $231-34$.

${ }^{70}$ CROss, supra note 60, at 246.

${ }^{71}$ Pope, supra note 61 , at xi.
} 
conservatism held at arm's length both Senator Joseph McCarthy (whose prominence was fast receding by 1954) and his vice president Richard Nixon, politics was politics, and the Executive Branch's expansion during the New Deal and its administrative prerogative over government secrets following the end of World War II constituted a source of political conflict. Democrats had controlled the Presidency since Franklin Roosevelt's election in 1932; now, even with a moderate war hero in the White House and a common enemy in the Soviet Union, the Congress viewed its role vis-à-vis an electoral foe as both a principled, institutional opposition to the Executive and a political opposition to a Republican. To that end, the House of Representatives' Government Operations Committee, chaired by Democratic Representative William Dawson of Illinois, established a Special Subcommittee on Government Information, chaired by California Representative John Moss, as a means to investigate Executive Branch secrecy. ${ }^{72}$

ASNE leaders and prominent newspaper editors played key roles in spurring the Subcommittee that Moss chaired (referred to popularly as "the Moss Committee") into action. ${ }^{73}$ The press provided personnel, with former journalists dominating the Committee's staff, while prominent editors helped devise its aggressive strategy of investigating federal agencies that kept information secret from the press and public. ${ }^{74}$ ASNE provided legal advice by introducing Cross to Moss and his Committee; Cross would play a key role as the Committee's legal advisor until his death in $1959 .^{75}$ The press also provided publicity, as newspapers throughout the country promoted the Committee's work and especially its hearings and investigations. ${ }^{76}$ And, through its lobbying and Cross's advice, the press helped

\footnotetext{
${ }^{72}$ On the political nature of the Moss hearings (at least in their early years), see Sam Archibald, The Early Years of the Freedom of Information Act-1955 to 1974, 26 PS: POL. SCI. \& POL. 726 (1993); Robert Okie Blanchard, The Moss Committee and a Federal Public Records Law, 1955-1965 (1966) [hereinafter Blanchard, Federal Public Records Law] (unpublished Ph.D. dissertation, Syracuse University) (on file with author); Richard G. Gray, Freedom of Access to Government Information (A Study of the Federal Executive) (1964) (unpublished Ph.D. dissertation, University of Minnesota) (on file with author). Dawson's appointment as chair of Government Operations in 1948 was contested, especially by southern Democrats, in part because he was African American; one of his strengths was his strong loyalty to party leadership. See CHRISTOPHER MANNING, WILLIAM L. DAWSON AND THE LiMITS OF BLACK ELECTORAL LEADERSHIP 119-21 (2009).

${ }^{73}$ Archibald, supra note 72 , at 726-27.

${ }^{74}$ Archibald, supra note 72, at 727; Blanchard, Federal Public Records Law, supra note 72, at 108-25; Kennedy, supra note 32, at 64-73.

${ }^{75}$ Kennedy, supra note 32, at 68-70, 94-96.

${ }^{76}$ Robert O. Blanchard, Present at the Creation: The Media and the Moss Committee, 1972 JOURNALISM Q. 271, 272-74 (1972) [hereinafter Blanchard, Present at the Creation].
} 
frame the issue for the Committee as one of insufficiently recognized and enforced legal rights. In James Pope's words when he testified at the Moss Committee's first hearing, "freedom of information is not a political issue... The right to know is the right of the people." 77 Tellingly, Harold Cross' argument in favor of imposing legal obligations through the creation of private statutory rights proved ultimately to be the only satisfactory legislative solution to secrecy. After an amendment to existing law failed to change bureaucratic norms ${ }^{78}$ the Freedom of Information Act - a statute whose very title was apparently appropriated from the title of ASNE member Herbert Brucker's 1949 book $^{79}$ - finally gained sufficient legislative support in 1966, cleared Congress's procedural hurdles, and was enacted despite President Johnson's ambivalence (if not resigned hostility). ${ }^{80}$

The FOIA enacted a version of a "right to know" and pledged to protect the informational "freedom" that had been first conceptualized and developed in the early post-war and Cold War effort to instill Western democratic values abroad through the ideal of a free, independent press. In its original enactment and in subsequent amendments, Congress has continually recognized and proclaimed the crucial role that the right to know and informational freedom play in a democracy ${ }^{81}$ - legislative declarations that courts have consistently restated when reviewing claims filed under the FOIA. ${ }^{82}$ The statute recognized an individual right

${ }^{77} \mathrm{Uhm}$, supra note 52, at 140; Kennedy, supra note 32, at 96.

${ }^{78}$ See Gerald Wetlaufer, Justifying Secrecy: An Objection to the General Deliberative Privilege, 65 IND. L.J. 845, 868-69 (1990). On the Subcommittee's frustrations with the inadequate results of its successful amendment to the 1789 Housekeeping Statute under which executive agencies refused to disclose documents, see Foerstel, supra note 57, at 33-35; Blanchard, Federal Public Records Law, supra note 72, at 127-35; Kennedy, supra note 32, at 90-92.

${ }^{79}$ Archibald, supra note 72, at 728; Blanchard, Present at the Creation, supra note 76, at 276; Kennedy, supra note 32, at 69-70. After Cross's death, Jacob Scher, another media lawyer and journalism professor, took his place as the Moss Committee's legal advisor and continued to follow Cross's approach. Blanchard, Federal Public Records Law, supra note 72, at 89-91, 138-39.

${ }^{80}$ Archibald, supra note 72, at 729-30; Blanchard, Federal Public Records Law, supra note 72, at 167210.

${ }^{81}$ See H.R. REP. No. 89-1497, at 12 (1966), reprinted in 1966 U.S.C.C.A.N. 2418, 2429 (“A democratic society requires an informed, intelligent electorate, and the intelligence of the electorate varies as the quantity and quality of its information varies.").

${ }^{82}$ See, e.g., NLRB v. Robbins Tire \& Rubber Co., 437 U.S. 214, 242 (1978) (“[T] he basic purpose of FOIA is to ensure an informed citizenry, vital to the functioning of a democratic society, needed to check against corruption and to hold the governors accountable to the governed."); EPA v. Mink, 410 U.S. 73, 80 (1973) ("[FOIA was] broadly conceived. ... to permit access to official information long shielded unnecessarily from public view and ... to create a judicially enforceable public right to secure 
to information and granted broad private rights to any person to seek judicial enforcement of those rights - rights that were themselves balanced against the state's need to keep some information from the public eye. ${ }^{83}$ Placing certain procedural burdens on agencies and creating a private right of action for aggrieved individuals, the FOIA delegated to the federal judiciary the task of protecting the right and enforcing the duties. Working together, Congress and the press had placed the right to know firmly within the institutional framework of the rule of law: agencies would henceforth have to follow legislatively prescribed rules enforced by the Judiciary, while the press would serve as a private enforcement mechanism, harnessing this newly established right to hold the government accountable and inform the public.

\section{Conclusion: The Limits of Law}

Traditional legal concepts - the judicial enforcement of individual rights and those of the press-animated and grounded an American open-government movement that viewed the state as a threat to democracy and press freedom. In its actions against the state, the press worked with state actors - an ironic element in any reformist, civil-libertarian movement and one that has remained consistent from the World War II period through FOIA's enactment. ${ }^{84}$ These efforts assumed and helped constitute an institutional structure for these rights: the press, acting as the public's agent, would advance and take advantage of the right to know; Congress and the courts would play key roles in helping to enforce them; and information would thereby be freed for the public to consume and act upon in its members' role as democratic citizens. The rhetoric was broad and the terms powerful because the stakes were so high. A democratic system demanded no less than committed political advocacy, especially in the midst of a Cold War that produced an enormous quantity of state secrets but that required a free and independent press to remain legitimate and accountable. ${ }^{85}$

such information from possibly unwilling official hands.”), superseded by statute, 5 U.S.C. § 552(b)(1), as recognized in C.I.A. v. Sims, 471 U.S. 159 (1985).

${ }^{83}$ Freedom of Information Act of 1966, Pub. L. No. 89-487, §§ (c), (e), 80 Stat. 250, 251 (requiring agencies to make records available to "any person" and providing private right of action to challenge an agency's refusal to disclose, while also enumerating exemptions to disclosure) (amended 1996).

${ }^{84}$ See DAVIES, supra note 57 , at 32.

${ }^{85}$ This campaign also represents the first instance in which the U.S. sought to export its ideals of press freedoms abroad, an idea that would largely end with the shift towards fighting government secrecy; it would later be resurrected in the 1990s, after the collapse of the Soviet Union. See CRAIG L. LAMAY, Exporting Press Freedom: ECONOMic and Editorial Dilemmas in International Media ASSISTANCE 76-84 (2007). 
The American FOIA is now merely one legislative enactment in a much broader universe of legal rights and duties created by constitutional and legislative mandates in order to advance some ideal or component of transparency. FOI provisions regulate government activity around the world as well as in American states and localities. ${ }^{86}$ The proliferation of legal rights has not created fully or, to many in the transparency-advocacy community, even satisfactorily open governments, as political, practical, and bureaucratic obstacles have obstructed the state's visibility to the public. ${ }^{87}$ In the U.S., the annual Sunshine Week and Freedom of Information Day events, established in 2005 to bring attention to freedom of information laws, include a regular declaration that more must be done to open government to the public's gaze. ${ }^{88}$ International FOI advocates express the same frustration with other nations' compliance with their own laws. ${ }^{89}$ Even when enacted, formal legal commands by themselves have not been able to overcome all forms and instances of governmental resistance to disclosure, whether that resistance is intended to hide corruption or incompetence, or as sincere efforts to protect internal deliberative processes, or simply because officials find it easier and less costly not to disclose information.

Despite these frustrations-or perhaps because of them-numerous FOI NGOs still actively advocate for a classically liberal, rights-focused approach to transparency and continue to view the press as the essential mediating institution

\footnotetext{
${ }^{86}$ On the international FOI movement, see Lawrence Repeta, Mr. Madison in the Twenty-first Century: Global Diffusion of the People's "Right to Know," in SOFT POWER SuPERPowers: Cultural AND National Assets of Japan and the United States 245, 250-55 (Watanabe Yasushi \& David L. McConnell eds., 2008); Thomas Blanton, The World's Right to Know, ForEIGN POL'Y, July-Aug. 2002, at 50; Greg Michener, FOI Laws Around the World, 22 J. DEMOCRACY 145, 145-46 (2011). On state FOI laws in the U.S., see 2 James T. O'Reilly, Federal InFormation Disclosure $§ 27$ (3d ed. 2010). For an introduction to the small universe of local FOI ordinances in the U.S., see Mark Fenster, Local Transparency (May 10, 2008) (unpublished manuscript) (on file with author).

${ }^{87}$ These frustrations began soon after FOIA's enactment. See JAMES BRIAN MCPHERSON, JOURNALISM At the END OF the American CENTURY, 1965-Present, at 50-51 (2006). On the difficulties of achieving a fully transparent state, see Mark Fenster, Seeing the State: Transparency as Metaphor, 62 ADMIN. L. REV. 617 (2010) [hereinafter Fenster, Seeing the State].

${ }^{88}$ See About Sunshine Week, SUnSHINE WEEK: YouR Right TO KNOw, http://www.sunshineweek.org/ About.aspx (last visited July 15, 2012).

${ }^{89}$ See, e.g., Lalanath de Silva, Freedom of Information Laws Spreading Around the World, WORLD RES. INST. (Sept. 26, 2010), http://www.wri.org/stories/2010/09/freedom-information-laws-spreadingaround-world (describing and celebrating new freedom of information laws but noting that "there is still a lot that needs to be done to improve implementation of these laws. Our research has shown that practice lags behind.").
} 
capable of enforcing legal rights and informing the public. ${ }^{90}$ But in part as a response to the frustrations that this resistance causes, and in part due to other factors - including developments in information technology, changing conceptions of the state, and the political economy of global commerce and international financial institutions (IFIs) — some contemporary advocacy groups have broadened their approach to understanding the asymmetric information problem, and champion new approaches to transparency that look beyond formal law and its enforcement. The remainder of this article outlines these alternative fixes to the problem of government secrecy-fixes that either view legal reform as part of a broader program or that abandon law altogether.

\section{The Administrative ANd InSTITUTiOnAl Fix: AnTI- CORRUPTION AS TRANSPARENCY}

Although it prominently incorporates transparency in its name and holds the transparency.org URL for its website, Transparency International (TI) is part of a movement that views transparency as one among a diverse set of tools that can achieve its larger goal of fighting corruption. TI puts transparency to work for a more specific, substantive goal than the FOI movement, which focuses more broadly on legal rights and a well-informed public. As this Part explains, TI advocates traditional legal rights to information but concentrates its efforts on building a transnational network of independent institutions that can fight corruption and distribute information on government performance, and that emphasizes economic development over democratic norms (without, to be sure, ignoring democratic norms entirely).

Before discussing transparency's role as a concept and policy goal in this movement, the movement and its more general project require some introduction. The transnational anti-corruption movement that TI helped spark advocates on behalf of administrative practices and institutional arrangements that can improve the integrity of states and their economies. ${ }^{91}$ It has both responded to and helped

\footnotetext{
${ }^{90}$ See supra note 6. Some such organizations, such as the Reporters Committee for Freedom of the Press (established in 1970) and the National Freedom of Information Coalition (established in 1989), have had longstanding and institutional commitments to supporting the press and are led by executives and board members from the institutional press and their legal representatives. See About The Reporters Committee for Freedom of the Press: A Short History, The ReP. Comm. For Freedom of the Press, http:// www.rcfp.org/about.html (last visited July 15, 2012); About NFOIC, NAT'L FREEDOM OF INFO. COALITION, http://www.nfoic.org/about-nfoic (last visited July 15, 2012); Board of Directors, NAT'L FREEDOM OF INFO. COALITION, http://www.nfoic.org/board-directors (last visited Nov. 8, 2011).

${ }^{91}$ On the then-nascent role of NGOs in the anti-corruption field, see SUSAN ROSE-ACKERMAN, CORRUPTION AND GOVERNMENT 168-71 (1999). Transparency International's history as the core NGO
} 
spread the widely-held view that corruption, which it defines as "the abuse of entrusted power for private gain," ${ }^{, 92}$ constitutes a problem endemic to developing nations and a leading cause of underdevelopment and poverty. For the anticorruption community, corruption's prevalence in the developing world helps explain the failure of the post-Cold War era to meet the potential offered by the global spread of democracy, the expansion of international trade, the privatization of inefficient state-owned enterprises, and the wealth created by extractive industries in resource-rich countries and regions. ${ }^{93}$ International financial institutions have more recently adopted measures that not only reflect the movement's influence but also suggest that IFIs themselves now act as part of the movement in forcing transparency on foreign development and financing projects. $^{94}$

Together, TI and similar NGOs, along with the IFIs and intergovernmental organizations that have come to emphasize anti-corruption as an integral reform to political and economic development, form what anthropologist Steven Sampson has characterized as an "anti-corruption industry"-a combined political movement and social network composed of international and national elites that sponsors conferences, policy reports, and journals, all in the name of promoting good

in this movement has been very well documented, both by TI members and by its critics. See Fredrik Galtung \& Jeremy Pope, The Global Coalition Against Corruption: Evaluating Transparency International, in THE Self-Restraining State: Power AND ACCounTABILITY IN NEW Democracies 257 (Andreas Schedler, Larry Diamond \& Marc F. Plattner eds., 1999) (account by TI's first managing director and original staff member); Luís de Sousa \& Peter Larmour, Transparency International: Global Franchising and the War of Information Against Corruption, in RESEARCH COMPANION TO CORRUPTION IN ORGANIZATIONS 269 (Ronald J. Burke \& Cary L. Cooper eds., 2009) (critical account of TI's history).

92 About Us, TRANSPARENCY INT'L, http://www.transparency.org/whoweare/organisation/faqs_on corruption/2/ (last visited July 15, 2012).

${ }^{93}$ See de Sousa \& Larmour, supra note 91, at 270, 272.

${ }^{94}$ Beginning in 1998, the International Monetary Fund began its own efforts to impose and evangelize in favor of "fiscal transparency" in governments receiving IMF support. Manual on Fiscal Transparency: Introduction, INT'L MONETARY FUND, http://www.imf.org/external/np/fad/trans/manual/intro.htm (last visited July 15, 2012). In 2010, the World Bank implemented a new Public Access to Information policy, representing what the Bank characterized as "a sea change" in its approach to information access that would broaden disclosure and "allow for greater monitoring of Bank-supported projects, thereby enabling better development results." News \& Broadcast: World Bank Broadens Public Access to Information, WORLD BANK (July 1, 2010), http://go.worldbank.org/L3HF51WOX0; see also Rebecca Harris, Knowledge Is Power: Transparency and Participation Will Be the Drivers of Effective Development, HufFINGTON POST (Apr. 19, 2011), http://www.huffingtonpost.com/rebeccaharris/knowledge-is-power-transp_b_851020.html; Stephanie Strom, Cracking Open the World Bank, N.Y. TIMES, July 3, 2011, at BU1. 
governance in general and an understanding of "transparency" in particular. ${ }^{95}$ In its international operations, the shared values and common discourse of its members, and its exchange of information and services among members and with state officials, this "industry" constitutes a "transnational advocacy network" akin to those developed by human-rights, labor, and feminist activists. ${ }^{96}$ Representative of the "new transnational activism" of global NGOs, TI and the anti-corruption movement mobilize resources against state structures and officials by working simultaneously at two distinct levels: rooting their efforts in specific national contexts (through, for example, TI's chapters and other national and local NGOs), while acting within transnational networks and furthering seemingly neutral, international norms of transparency. ${ }^{97}$ Significantly, however, TI and its allies depart from this broader trend by eschewing the "counterhegemonic" and rightsfocused, left-wing projects that those other networks attempt to further; ${ }^{98}$ instead, the anti-corruption community works with established IFIs and other international institutions to further the financial integration of developing nations within global capitalism. $^{99}$

${ }^{95}$ Steven Sampson, The Anti-Corruption Industry: From Movement to Institution, 11 GLOBAL CRIME 261, 276-77 (2010). Prominent human rights NGOs with agendas that look beyond anti-corruption, such as Amnesty International, have also begun to promote transparency campaigns. TI and AI occasionally work together in broader campaigns to end human rights abuses and corruption. See, e.g., Middle East and North Africa Can End Legacy of Human Rights Abuse and Corruption, AMNESTY INT'L (Mar. 11, 2011), http://www.amnesty.org/en/for-media/press-releases/middle-east-and-northafrica-can-end-legacy-human-rights-abuse-and-corrupti (joint announcement by AI and TI calling for new governments coalescing after the so-called Arab Spring to establish, among other things, "processes for consultation and access to information that allow human rights activists and all other civil society actors to participate fully and without fear in the building of systems and institutions of government").

${ }^{96}$ MARgaret E. KeCK \& KATHRYN SiKKINK, ACTIVISTS BEyOND Borders: AdVOCACy NeTWORKS IN INTERNATIONAL POLITICS 2 (1998).

${ }^{97}$ See Sidney Tarrow, The New Transnational Activism 28-29 (2005).

98 See Peter Evans, Counterhegemonic Globalization: Transnational Social Movements in the Contemporary Global Political Economy, in The HandBook of Political Sociology: STATEs, Civil Societies, AND GlobalizATION 655, 656-58 (Thomas Janoski et al. eds., 2005); Philip McMichael, Globalization, in HANDBOOK OF POLITICAL Sociology, supra, at 587, 588-90. These counterhegemonic movements have themselves been subject to important critiques from the left. See, e.g., Janet Halley, Rape at Rome: Feminist Interventions in the Criminalization of Sex-related Violence in Positive International Criminal Law, 30 MiCH. J. INT'L L. 1, 4 (2009) (critiquing the international feminist movement); David Kennedy, The International Human Rights Movement: Part of the Problem?, 15 HARV. HUM. RTS. J. 101, 109-10 (2002) (critiquing international human rights organizations); Kelly Rittich, Global Labour Policy as Global Social Policy, 14 CAN. LAB. \& EMP. L.J. 227 (2008) (critiquing international labor organizations).

${ }^{99}$ In this regard, the anti-corruption movement is decidedly not a "social movement" that would fall within the sociological subfield that studies such movements - it is far more top-down than bottom-up, 


\section{A. "Transparency" in Transparency International}

TI was founded in 1993 under the leadership of former World Bank executive Peter Eigen and thus was one of the first and most prominent non-governmental members of the anti-corruption movement. ${ }^{100}$ It has expanded to include nearly one hundred accredited national chapters that lobby and pressure public decisionmakers in the many countries in which it operates to adopt corruption control instruments. ${ }^{101}$ Lacking the power or leverage that international and regional governing bodies - like the UN or the Organization of American States, and IFIs, like the World Bank and IMF - enjoy, TI tries to use its professional networks and moral authority to build coalitions among government, private-sector, and civilsociety institutions. ${ }^{102}$ In its overarching policy platform, TI prescribes a portfolio of legal and structural measures that extend well beyond forcing the state to disclose information to the public. $^{103}$ These strategies include using the

as its institutional relationship with the World Bank, see text accompanying supra note 94, demonstrates. See Amy Kapczynski, The Access to Knowledge Mobilization and the New Politics of Intellectual Property, 117 YALE L.J. 804, 806-07 n.2 (2008) (parsing definitions and noting that the term transnational advocacy network is generally identified predominantly with "professionalized NGO advocacy"); Michael McCann, Law and Social Movements: Contemporary Perspectives, 2 ANN. ReV. L. \& Soc. SCI. 17, 23-24 (2006) (providing literature review of social movement theory and identifying among its many themes a focus on movements led by and representing "nonelites whose social position reflects relatively low degrees of wealth, prestige, or political clout" and a use of disruptive protests and other tactics "that halt or upset ongoing social practices").

${ }^{100}$ Galtung \& Pope, supra note 91, at 258. TI's founding coincided with, and helped spur, the development in the mid- to late-1990s of an international consensus among IFIs and other state and nonstate entities to view corruption as a preeminent obstruction to economic development. See James Thuo Gathii, Defining the Relationship Between Human Rights and Corruption, 31 U. PA. J. INT'L L. 125, $144-45$ (2009). It also coincided with the beginning of a period in the history of NGOs in which NGOs were increasingly active and influential in international policymaking. See Steve Charnovitz, Two Centuries of Participation: NGOs and International Governance, 18 Мich. J. INT'L L. 183, 265-68 (1997).

${ }^{101}$ Galtung \& Pope, supra note 91, at 260; de Sousa \& Larmour, supra note 91, at 270, 273-77; Luís de Sousa, TI in Search of a Constituency: The Institutionalization and Franchising of the Global AntiCorruption Doctrine, in GOVERnMENTS, NGOs AND ANTI-CORRUPTION: THE NEW INTEGRITY WARRIORS 186, 194-96 (Luís de Sousa, Peter Larmour \& Barry Hindess eds., 2009).

${ }^{102}$ Kenneth W. Abbott \& Duncan Snidal, Values and Interests: International Legalization in the Fight Against Corruption, 31 J. Legal STUD. S141, S165-66 (2002); Peter Eigen, Measuring and Combating Corruption, 5 J. POL'y REF. 187, 190 (2002); A Statement of Vision, Values and Guiding Principles for Transparency International, TRANSPARENCY INT'L (Oct. 16, 2011), http://www.transparency.org/ whoweare/accountability/a_statement_of_vision_values_and_guiding_principles_for_ti/2/.

${ }^{103}$ The anti-corruption movement of which TI is a part intersects with broader international movements promoting good governance, democracy promotion, economic development, and state building. Steven Sampson, Corruption and Anti-Corruption in Southeast Europe: Landscapes and Sites, in GOVERNMENTS, NGOS AND ANTI-CORRUPTION, supra note 101, at 170. 
organization's institutional structures, which produce research and model reforms and build networks among states, IFIs, and other NGOs, to lobby and pressure for various reforms. TI and the broader anti-corruption movement encourage states to enact and enforce ethical standards among officials and corporations contracting with governments, to offer higher salaries to government employees, to privatize state-owned enterprises and services, and to enact laws and develop norms that promote transparency and thereby bring corrupt practices to light. ${ }^{104}$

With the prominent position that it plays in the name of one of the most widely recognized anti-corruption NGOs, transparency enjoys special status among the package of good-government reforms that the movement promotes. ${ }^{105}$ TI advocates on transparency's behalf both by lobbying for rights-based legal reforms (whether at the national level or via the enforcement of international conventions) and by collecting and distributing information about government performance. As it states on its website,

Transparency International supports the international efforts to have the right of access to information recognised and respected. The exercise of this right enables citizens to keep their governments and public bodies accountable. This can hinder corrupt practices that benefit from opaque or obscure regimes. ${ }^{106}$

TI also collects and publicizes information about corrupt practices, most prominently in its Corruption Perception Index (CPI). ${ }^{107}$ The CPI is an "aggregate indicator" that uses assessments and business opinion surveys to gauge the extent of a nation's corruption and the extent of its anti-corruption efforts in the public

104 Ed Brown \& Jonathan Cloke, Neoliberal Reform, Governance and Corruption in the South: Assessing the International Anti-Corruption Crusade, 36 ANTIPODE 272, 275-77 (2004); Galtung \& Pope, supra note 91, at 261-74.

105 See Margaret Hanson, The Global Promotion of Transparency in Emerging Markets, 9 GLOBAL GOVERNANCE 63, 66-68 (2003). To its great credit, TI also has also attempted aggressively to disclose the sources of their own funding - a practice that other transparency-focused NGOs have adopted. See Frequently Asked Questions about Transparency International, TRANSPARENCY INT'L, http:// www.transparency.org/whoweare/organisation/faqs_on_transparency_international/2/ (last visited July 15, 2012) (explaining how TI is funded and how its national chapters are financed independently); see also How We Are Funded, EXTRACTIVE InDUS. TRANSPARENCY InITIATIVE, http://eiti.org/ about/funding (last visited Nov. 8, 2011).

106 The Role of Information in Fighting Corruption, TRANSPARENCY INT'L, http://archive .transparency.org/global_priorities/access_information (last visited July 15, 2012).

${ }^{107}$ For a list and description of TI's full range of reports, see Publications, TRANSPARENCY INT'L, http://www.transparency.org/whatwedo/publications/ (last visited July 15, 2012). 
sector. It then scores each nation on a ten-point scale that allows comparisons across countries. ${ }^{108}$ It has become TI's signature product and a key element of its brand identity. ${ }^{109}$ TI's approach has served as a model for new entrants in the anticorruption field, which use similar approaches to protect developing nations from corrupt practices in the extractive industries (where corruption is often endemic) $)^{110}$ or to offer an index of laws and government practices that competes with and complements TI's CPI. ${ }^{111}$

If the anti-corruption industry adapts, at least in part, a traditional rights-based strategy for opening government, its focus on the economic and political effects of corruption distinguishes its understanding and use of transparency as an issue. The industry views NGO-produced measures that force disclosure on state actors-like the other good-governance measures that it advocates - as a means to make a nation's government more ethical, its markets more efficient, and its economy more robust. It thereby reverses the FOI movement's assumptions about transparency's primacy in democratic theory and practice: rather than understanding law as a means to make the state transparent and therefore more democratic (with the help of the private press), the anti-corruption movement views transparency and the international NGOs that define and enforce it as the means to reach an economic and administrative goal - the end of official corruption - that will ultimately reform a nation's political system. Although its name has played a

\footnotetext{
108 Corruption Perceptions Index 2010, TRANSPARENCY INT'L, http://www.transparency.org/policy_ research/surveys_indices/cpi/2010/results (2010).

109 See Staffan Andersson \& Paul M. Heywood, The Politics of Perception: Use and Abuse of Transparency International's Approach to Measuring Corruption, 57 POL. STUD. 746, 747 (2009).

${ }^{110}$ The most prominent extractive-industry NGOs are the Extractive Industries Transparency Initiative, founded in 2002 and funded by the private sector, supporting countries, civil-society organizations, and its host government, Norway, and Publish What You Pay, also founded in 2002 and formed and initially funded by NGOs and foundations. See EXTRACTIVE InDUS. TRANSPARENCY InITIATIVE, http://eiti.org (last visited Nov. 15, 2011); PUBLISH WHAT YOU PAY, http://www.publishwhatyoupay.org (last visited July 15, 2012). Their campaigns attempt to force companies to, as the name states, "publish what [they] pay" for the right to extract, in order to make such transactions more transparent.

${ }^{111}$ A recent entrant in the field is Global Integrity (GI), begun in 1999 within the Center for Public Integrity (a U.S. domestic investigative journalism NGO) and then spinning off independently in 2005, with a mission to "play a catalytic role in promoting accountability and transparency reforms by developing tools that address the needs of the public, private, and civil sectors equally." Global Integrity's Mission, GLOBAL INTEGRITY, http://www.globalintegrity.org/about/mission (last visited July 15, 2012). Rather than studying perceptions of corruption like TI, GI assesses anti-corruption mechanisms, openness, and government accountability to understand not what it describes as the "disease of corruption" but "the medication applied against it: the public policies, institutions, and practices that deter, prevent, or punish corruption." Our Story, GLOBAL INTEGRITY, http://www.globalintegrity.org/about/story (last visited July 15, 2012).
} 
key role in the emergence of "transparency" as the term that signifies open government, TI neither seeks transparency for its own democratic sake nor privileges it as the most important tool on the role to a legitimate state. Instead, TI promotes the consequential value of openness as a means to fight corruption.

\section{B. The Contestable Claims of the Institutional Anti-Corruption Fix}

TI's fight against corruption and on transparency's behalf has not gone unchallenged. Critics argue that despite its seemingly precise, quantitative, and unambiguous calculation of corruption, TI's CPI relies on imprecise perceptions and flawed sampling and survey methodologies. ${ }^{112}$ They also claim that the anticorruption movement furthers Western, technocratic conceptions of governance and a neoliberal vision of a minimal state; ${ }^{113}$ as applied in the nations that the CPI identifies as suffering from corruption, anti-corruption programs shrink the size of government and limit its functions while expanding institutional and legal accountability regimes. ${ }^{114}$ In the process, seemingly universal ideals of a good government, developed and promoted by Western NGOs funded by Western governments and foundations, ${ }^{115}$ are imposed on distinct political, economic, and social systems of individual nations. These prescriptions prioritize "good government" over popular democracy and effective, legitimate policy for the entire

\footnotetext{
${ }^{112}$ The CPI's seeming precision in reducing a complex phenomenon to an ordinal rating is a key feature that helps win it media attention when TI releases it annually. See de Sousa \& Larmour, supra note 91, at 277-78. For criticisms of the CPI, see Andersson \& Heywood, supra note 109, at 752-54; Christiane Arndt \& Charles Oman, OeCD Dev. Ctr., Uses and Abuses of Governance INDICATORS 91-92 (2006). Critics of the extractive industries similarly charge that indices such as that produced by the Extractive Industry Transparency Initiative enable mining and oil companies to appear ethical while they seek additional rents from resource-rich nations and hide profits through corporate subsidiaries and tax havens. See NNimmo BASSEy, To CoOK A Continent: Destructive EXTRACTion AND Climate Crisis IN AFrica 35-39 (2011); Khadija Sharife, "Transparency" Hides Zambia's Lost Billions, AL JAZEERA ENG. (June 18, 2011, 3:43 PM), http://www.aljazeera.com/indepth/opinion/ 2011/06/20116188244589715.html.

${ }^{113}$ For a broader critique of NGOs' role in promoting a neo-liberal globalization, see JEAN-FRANÇOIS Bayart, Global SubJects: A Political Critique of Globalization 58-67 (2007).

114 TI's rise has run concurrently with the rise of New Public Management (also known as New Governance), whose emphasis on accountability has proven especially attractive to the diverse political interests that advocate for public fiscal restraint, particularly in the provision of public services. See Michael Power, The Audit Society: Rituals OF Verification 43-44 (1997).

115 See Frequently Asked Questions About TI, TRANSPARENCY INT'L, http://transparency.org/news $\mathrm{room} / \mathrm{faq} / \mathrm{faq}$ ti ("The bulk of TI's income comes from government development agency budgets and foundations. Other sources of income include project funds from international organisations, donations from private sector companies and income from honoraria and publications.").
} 
nation, while the pursuit of these ideals limits the range of political issues that voters and their elected representatives can decide. ${ }^{116}$ The CPI thus acts as a disciplining technology, one whose seeming, but imperfect, neutrality and basis in the administrative norm of transparency constitutes a form of unelected "organized governance" on states and their agencies while it hides its more normative, programmatic functions. ${ }^{117}$ Representing ideas developed elsewhere, and wielding powerful, seemingly objective indices to advocate for government reform, TI and international anti-corruption advocates appear unaccountable to local citizens and publics - even as they would claim to be furthering the crucial political and public goal of fighting official corruption. ${ }^{118}$

TI responds to such critiques by arguing that ending the easy cases of clear corruption (e.g., the official with the Swiss bank account) are the main,

116 See Brown \& Cloke, supra note 104, at 285; Staffan Andersson \& Paul M. Heywood, AntiCorruption as a Risk to Democracy: On the Unintended Consequences of International Anti-Corruption Campaigns, in GOVERnMENTS, NGOS AND ANTI-CORRUPTION, supra note 98, at 33-34; Barry Hindess, Good Government and Corruption, in CORRUPTION AND ANTI-CORRUPTION 1, 5-7 (Peter Larmour \& Nick Wolanin eds., 2001); Barry Hindess, International Anti-Corruption as a Programme of Normalization, in GOVERNMENTS, NGOS AND ANTI-CORRUPTION, supra note 101, at 19-32 [hereinafter Hindess, Normalization]; Peter Larmour, Corruption and the Concept of "Culture": Evidence from the Pacific Islands, 49 CRIME, L. \& Soc. Change 225, 237 (2009). For a classic study of the unintended negative consequences of imposing anti-corruption reforms, see FRANK ANECHIARICO \& JAMES B. Jacobs, The Pursuit of Absolute InTEgrity: How Corruption Control MaKes Government INEFFECTIVE (1996).

117 See Andersson \& Heywood, supra note 109; Brown \& Cloke, supra note 104; see also JoN Beasley-Murray, Posthegemony: Political Theory and Latin America 107-08 (2011) (critiquing transparency's transformative power on the state and society, and its relationship to neoliberalism); POWER, supra note 114, at 6-8 (noting the distinction in financial accounting between technological, or operational, elements of auditing practices and programmatic, or normative, elements, while both problematizing the idea that technology is neutral and noting how its seeming neutrality obfuscates the programmatic nature of the practice). For a critique of how seemingly neutral standards serve as normative efforts to control behavior and organize governance, see NILS BRUNSSON \& BENGT JACOBSSON, The Contemporary Expansion of Standardization, in A WORLD OF STANDARDS 1, 10 (2000); Haridimos Tsoukas, The Tyranny of Light: The Temptations and Paradoxes of the Information Society, 29 FUTURES 827, 831 (1997).

${ }^{118}$ For criticism of NGOs as unrepresentative of local populations and unaccountable to national political systems, see Kenneth Anderson \& David Rieff, "Global Civil Society": A Sceptical View, in Global Civil SocieTY 2004/05, at 26, 29-30 (Helmut Anheier et al. eds., 2005); Ruth W. Grant \& Robert O. Keohane, Accountability and Abuses of Power in World Politics, 99 Am. Pol. Sci. Rev. 29, 37-38 (2005); Peter J. Spiro, New Global Potentates: Nongovernmental Organizations and the "Unregulated" Marketplace, 18 CARDOzo L. REv. 957, 963 (1996); see also Steve Charnovitz, Nongovernmental Organizations and International Law, 100 AM. J. INT'L L. 348, 365-68 (2006) (agreeing with Anderson and Rieff in part, but arguing that "more open and inclusive processes of decision making can help to overcome the allegedly attenuated democratic legitimacy of international governance"). 
uncontroversial purpose of its work, ${ }^{119}$ and that it allows its locally situated national chapters to define corruption in more difficult cases. ${ }^{120}$ In other words, eradicating clear cases of corruption is not political, and the organization leaves a broad array of political and regulatory options open to its locally accountable and informed members. But anti-corruption efforts do not simply seek to identify and punish wrongdoers; they also advocate, implicitly or explicitly, broader structural reforms. And if corruption is defined narrowly as rent-seeking behavior by public officials, then privatization and deregulation - reform strategies that can apply in any setting - simultaneously reduce the potential for corruption and make the state ostensibly more transparent by making it smaller. ${ }^{121}$ To the extent that TI and the anti-corruption movement market these reforms as administrative, technocratic improvements provided by independent, non-state institutions, their efforts seem to promote neutral, common-sense tools that can transform states into leaner, more efficient institutions - states that can both be held accountable to a Western model cognizable to NGOs and IFIs and be more attractive to direct foreign investment. ${ }^{122}$ These seemingly neutral principles are the very problem that TI represents for its critics, who view the NGO as either a witting or unwitting agent of a global neoliberal regime that undercuts state sovereignty and local control. ${ }^{123}$ "Transparency," for TI and the anti-corruption movement generally, functions both as a transcendent and neutral administrative norm to which all reasonable people can subscribe and as the basis for a normative political apparatus that plays a key role in the structural readjustment of national political, economic, and administrative systems. One need not fully agree with commentators who are critical of the anti-corruption movement in order to view the powerful normative

${ }^{119}$ Frequently Asked Questions About Corruption, TRANSPARENCY INT'L, http://www.transparency.org/ whoweare/organisation/faqs_on_corruption/2/ (last visited July 21, 2012).

${ }^{120} \mathrm{Id}$.

${ }^{121}$ Brown \& Cloke, supra note 104, at 286-87.

${ }^{122}$ Hanson, supra note 105, at 63; Hindess, Normalization, supra note 116, at 23; Mark Philp, Modelling Political Corruption in Transition, in Dimensionen POLITISCHER KoRRUPTION: BeITRA GE ZUM STAND DER INTERNATIONALEN FORSCHUNG 91, 96 (2005).

${ }^{123}$ On transparency's relationship to global neoliberalism, see ZYGMUNT BAUMAN, GLOBALIZATION: THE HUMAN CONSEQUENCES 29-33 (1998) (characterizing the expert imposition of transparency as a means to ease administration over differentiated, local cultures); Christina Garsten \& Monica Lindh de Montoya, The Naked Corporation: Visualization, Veiling and the Ethico-Politics of Organizational Transparency, in TRANSPARENCY IN A New Global ORDER, supra note 15, at 79, 90-91 (describing transparency as a seemingly moral, apolitical means to "mak[e] the globalizing world hospitable for trans-organizational, transnational and sometimes super-national interventions and administrative procedures"). 
role that the movement plays in the political economy of good governance reforms that are promoted, sometimes coercively, by international institutions.

\section{Conclusion: The Limits of the Institutional Anti-Corruption Fix}

An open, visible state is one aspect, albeit a key one, in TI's broader critique of governing regimes around the world and its normative vision for a leaner, more accountable, and efficient state. The problem TI and the broader movement principally address is corruption, not a democratic deficit created and fostered by official secrecy or a political right that the state is ignoring or under-enforcing. They pursue reform as a means to extend the larger structural, historical change of which they are a part: the expansion and movement of global capital and finance to fund economic development as it is understood and championed by Western states. $\mathrm{TI}$ and its institutional colleagues thus hold a primarily consequentialist vision of transparency, one in which transparency's democratic effects flow from better, non-corrupt governance rather than from the enforcement of the public's right of access to information as such. ${ }^{124}$

It is a vision whose suspicion about the state and law are more pronounced than in the earlier FOI movement. If the state is corrupt, it will not enact laws to force itself to disclose information, and if the corrupt state has such laws, it will under-enforce them. Like other transnational NGOs, TI thus attempts to work around the state by helping to construct an institutional network of organizations that can force the state to disclose information ${ }^{125}$ and affect international law and norms. ${ }^{126}$ With its international organization and national chapters, as well as its relationships with influential IFIs, developed nations, and private firms, TI relies for reform on a far more complex set of institutional actors than the administrative procedures and judicial review that the traditional FOI movement envisions. Furthermore, its reliance upon local chapters recognizes that its program will vary in different countries, based on local political, legal, and institutional conditions. TI thus hopes to further a transnational ideal of non-corrupt governance without necessarily seeking to impose a transcendent legal right of public access to

\footnotetext{
${ }^{124}$ On consequentialist arguments in transparency's favor, see Fenster, supra note 3, at 899-902.

${ }^{125}$ This process, in which local activists whose work is blocked by the state seek assistance from international NGOs whose headquarters are elsewhere to provide external pressure, is referred to as the "boomerang" effect in the literature on transnational activism. See KECK \& SiKKINK, supra note 96, at 12-13; TARROW, supra note 97, at 145-46.

${ }^{126}$ See Steve Charnovitz, Nongovernmental Organizations and International Law, 100 AM. J. INT’L L. 348, 361-63 (2006).
} 
U N I V E R S I T Y O F P I T T S B U R G H L A W R E V I E W

PAGE

information - the ideal of a constitutional and human right that should allow no national variance.

These distinctions reflect the quite different historical context from which the anti-corruption movement emerged. The Cold War had ended by the time TI began, removing world communism as the main threat to the developing world and reshaping the bipolar geopolitics that the West and East had seemed to inhabit. But corruption serves an analogous role to TI in post-communist, failed, and developing states as the Soviet threat did to ASNE and free press advocates focused on the immediate post-war world. Economic development has replaced democratic development as the preeminent concern, and administration and governance that can attract foreign capital and IFI loans and investment serve the role that legal informational rights and a free press played and continue to play for the FOI movement.

\section{The Technological Fix: Digital Transparency}

FOI advocates view government information asymmetry and hoarding primarily as creating state secrecy and as correctable with a legal solution. TI and other anti-corruption advocates view the same problem as a largely administrative one caused by official corruption, which an institutional solution can solve. Digitaltransparency advocates view the same problem primarily as one of the flow and accessibility of data, which can be solved through information technology. In their solution, code and networked communication substitute for or augment the legal rights and duties that officials routinely ignore and courts insufficiently enforce, effectively and efficiently moving government information from hard drives and other storage media to the public. Reframing the problem that transparency must solve from law to code leads digital advocates to prescribe a smaller role for the state (as well as for the institutional press) than the earlier advocacy movement and a much larger role for an active, participatory citizenry and an entrepreneurial class of visionaries and software designers. Although some digital-transparency NGOs attempt to further the more traditional aims of the FOI movement, ${ }^{127}$ the

\footnotetext{
${ }^{127}$ The Sunlight Foundation, for example, has established a wide range of online programs that overlap with traditional freedom of information and campaign finance disclosure laws, and is focused especially on making congressional operations more visible via the Internet. See Issues by Topic, SunLIGHT FounD., http://sunlightfoundation.com/about/issues/ (last visited July 21, 2012) (listing the projects it is pursuing, which includes disclosing congressional earmarks, participating in the FOI campaign's Sunshine Week and Freedom of Information Day, and attempting to increase the transparency of lobbyists' influence); see also Schacter, supra note 18, at 651 (discussing Sunlight Foundation programs). Micah Sifry, co-founder of the Personal Democracy Forum, similarly views at least part of the NGO's purpose as using digital information and networking technology to take advantage of and
} 
movement's innovation lies in its distinct efforts to free government data and allow information to move freely between state and public.

\section{A. Digital Transparency and the Technological Transformation of State and Public}

The rhetoric that digital-technology advocates deploy is remarkably powerful, continuing a tradition established in the writings that heralded the emergence of cyberspace. ${ }^{128}$ The foremost collection advocating this position, entitled Open Government: Collaboration, Transparency, and Participation in Practice (2010) and issued by the technology book publisher O'Reilly, ${ }^{129}$ includes essays proclaiming that the revolutionary changes wrought by information technology can tame and make usable the data collected and produced by sprawling government bureaucracies. The book's contributors provide a representative sampling of the movement's composition and leadership: NGO executives and staff, entrepreneurial software programmers as well as executives and in-house intellectuals at Microsoft and IBM, academics (both faculty and enterprising students), consultants, and several government officials from federal agencies and congressional staff as well as from state and local government. The Internet, the book's foreword states, can and will produce a state that

opens its doors to the world; co-innovates with everyone, especially citizens;

shares resources that were previously closely guarded; harnesses the power of mass collaboration; drives transparency throughout its operations; and behaves

further the spirit of FOI laws. See Micah L. Sifry, WikiLeaKs AND the Age Of TransParency 10534 (2011).

${ }^{128}$ See generally PATRICE FLICHY, THE INTERNET IMAGINAIRE (2007) (documenting the utopian claims made on the Internet's behalf, especially in the early 1990s); FRED TURNER, FROM COUNTERCULTURE TO CyBerCulture 249-62 (2005) (providing an intellectual history of the utopian claims about cyberspace and the Internet); Philip Agre, The Market Logic of Information, 13 KNOWLEDGE, TeCH. \& POL'Y 67 (2000); Richard Barbrook \& Andy Cameron, The Californian Ideology, 6 SCI. AS CULTURE 44, 67 (1996) (offering a relatively early critique of cyber-utopianism); Julie E. Cohen, Cyberspace As/And Space, 107 Colum. L. Rev. 210, 215-19 (2007) (summarizing the utopian strain in cyberspace advocacy). The classic example is John Perry Barlow, The Economy of Ideas, WIRED, Mar. 1994, at 84, 89, 129 (reiterating, explaining, and making famous Stewart Brand's claim that "information wants to be free," and predicting that "[ $[$ the [intellectual property] protections that we will develop will rely far more on ethics and technology than on law").

${ }^{129}$ Open Government: Collaboration, Transparency, and Participation in Practice (Daniel Lathrop \& Laurel Ruma eds., 2010) [hereinafter OPEN GOVERNMENT]. 
U N I V E R S I T Y O F P I T T S B U R G H L A W R E V I E W

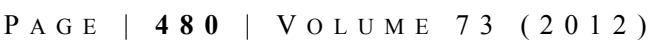

not as an isolated department or jurisdiction, but as something new-a truly integrated and networked organization. ${ }^{130}$

This new state will surely be leaner and more efficient; moreover, as it "coinnovates," "shares resources," collaborates, "drives transparency," integrates, and networks, it will also act in a less hidebound, formally bureaucratic way.

Such ideals suggest administrative and technical commitments that parallel the open source code movement. In his key chapter in the aforementioned digitaltransparency book (published by the company he founded), Tim O'Reilly offers a series of "lessons" from the open source community and technology industry that he argues apply directly to government: use open, simple programming standards; design information technology to foster participation; and enable end users to mine and aggregate data the state collects. ${ }^{131}$ "Just as open source software allows users to change and contribute to the source code of their software," the book's editors note in its preface, "open government now means government where citizens not only have access to information, documents, and proceedings, but can also become participants in a meaningful way." 132 The technology and process of open source, advocates argue, will increase the state's visibility and ability to collaborate with the public. ${ }^{133}$ Its ability to evoke among technophiles technical competence, open design, and collaborative process also allows "open source" to serve as the key metaphor among popular political theorists who deploy it in such concepts as "open-source democracy,"134 "open-source politics,"135 and "next generation democracy.","136

\footnotetext{
${ }^{130}$ Don Tapscott, Foreword to OpEn GOVERnMENT, supra note 129, at xvi.

${ }^{131}$ Tim O'Reilly, Government as Platform, in OPEN GOVERNMENT, supra note 129, at 11, 15-24, 32-34.

${ }^{132}$ Daniel Lathrop \& Laurel Ruma, Preface to OPEN GOVERnMENT, supra note 129, at xix, xix.

${ }^{133}$ Danielle Keats Citron, Open Code Governance, 2008 U. ChI. Legal F. 355, 371-87; cf. LAWrence LESSIG, CODE: VERSION 2.0, at 153 (2006) ("'Open code] functions as a kind of Freedom of Information Act for network regulation. As with ordinary law, open code requires that lawmaking be public, and thus that lawmaking be transparent.").

134 See Douglas Rushkoff, Open Source Democracy: How Online Communication Is ChANGing OfFline Politics (2003), available at http://www.gutenberg.org/catalog/world/ readfile?fk_files $=1477887$.

${ }^{135}$ See Micah Sifry, The Rise of Open-Source Politics, NATION, Nov. 4, 2004, at 14, available at $\mathrm{http} / / / \mathrm{www}$.thenation.com/article/rise-open-source-politics.

136 See Jared Duval, Next Generation Democracy: What the Open-Source Revolution MEANS FOR POWER, POlitics, AND CHANGe (2010).
} 
That degree of productivity and enthusiasm about newly emergent technological possibilities brims over in events like TransparencyCamp, an annual event held outside Washington, D.C., where "government officials, technologists, journalists and advocates [come together] to share their knowledge about how best to use new technologies and policies to make our government really work for the people." 137 A project of the Sunlight Foundation, a leading digital-transparency NGO, the Camp's 2011 "unconference" was sponsored by Microsoft (on whose Maryland campus the event was held), Google, O'Reilly Publishing, Governing magazine, Adobe, and Forum One Communications (a "digital communications firm" that develops internet strategies for, among others, NGOs and government agencies). ${ }^{138}$ Scheduled sessions in 2011 included varied topics like "Building an Open Financial Datamart," "Breaking the Information Cartel in Congress," and "Open Data in Municipal Government for Fun and Profit." "139 As one activist described it in a video posted on the Sunlight Foundation website, "It's a beautiful citizen uprising, but it's not an uprising which says we've come here to destroy or tear you down, it's an uprising that says we've come here to help you be more efficient." ${ }^{140}$ Led by young activists and visionary officials, the TransparencyCamp "uprising" is built upon and via the hardware, software, and search engines of its eminent corporate sponsors.

Coupling rhetorical verve with organizational energy, digital-transparency advocates posit that the state and public can engage in ongoing, two-way communication - a much broader and bolder vision than the FOI movement's more restrained idea that the public's right to know will increase government accountability and improve bureaucratic performance. Before, "information" needed to be "freed" to the public via the press; now, as usable data, it can, must, and will flow freely and cheaply in all directions, using technology that allows twoway access to the state. ${ }^{141}$ Data running freely can move from the state as well as to

${ }^{137}$ About Transparency Camp, TRANSPARENCY CAMP, http://transparencycamp.org/ (last visited Nov. 9, 2011); Sponsors, TRANSPARENCY CAMP, http://transparencycamp.org/sponsors/ (last visited Nov. 9, 2011).

${ }^{138}$ Sponsors, supra note 137.

${ }^{139}$ Schedule, TRANSPARENCY CAMP, http://transparencycamp.org/sessions/ (last visited July 21, 2012).

${ }^{140}$ TransparencyCamp 2011, video embedded in Laurenellen McCann, TCamp: Looking Back and Looking Forward, SunLIGHT Found. BLOG (May 12, 2011, 1:18 PM), http://sunlightfoundation.com/ blog/2011/05/12/tcamp-looking-back-and-looking-forward/.

141 See, e.g., Beth Simone Noveck, Wiki Government: How Technology Can Make Government Better, Democracy Stronger, and Citizens More Powerful, at xii-xiii (2009) (characterizing the ideal of "open government" as concerning both data access and collaboration with the public). 
it; the public can both pull information from the state and push data and opinions to it. A digital world thus should enable unmediated, interactive communication between state and citizens, an ideal that digital technology NGOs like the Sunlight Foundation and the Personal Democracy Forum embrace. ${ }^{142}$

Digital transparency's ideals dovetail with, and could even advance, the main administrative reform movements of the past several decades. ${ }^{143}$ Like the deregulatory "new public management" movement, ${ }^{144}$ digital transparency imagines citizens as consumers who can use government data to make better market decisions, and views private entities as capable of improving upon or replacing state-created public goods and services. ${ }^{145}$ Similarly, in its effort to have government collaborate with private citizens and institutions in designing regulatory programs and public-service provisions ${ }^{146}$ digital transparency also parallels and incorporates "new governance" ideals. ${ }^{147}$

${ }^{142}$ See, e.g., SIFRY, supra note 127, at 15-17 (editor and curator of the Personal Democracy Forum, praising the "Age of Transparency" in an era of networked communication, in which social media and so-called "crowd-sourced" information are viewed as inexorably changing the shape of the government and its relationship to its citizens); Sunlight Agenda 2011, SunLIGHT Found., http:// sunlightfoundation.com/policy/documents/agenda/ (last visited July 21, 2012) ("Today, our newly networked citizenry has rising expectations of greatly expanded access to governmental information, so that it may play a fuller role in understanding, evaluating and participating in the workings of its government. More open and transparent government can foster more competent and trustworthy behavior by public officials along with a more engaged public.").

${ }^{143}$ See generally Jennifer Shkabatur, Cities @ Crossroads: Digital Technology and Local Democracy in America, 76 BROOK. L. Rev. 1413, 1443-64 (2011).

144 See generally Christopher Ansell \& Jane Gingrich, Reforming the Administrative State, in Democracy TRANSFORMED? 164, 165-66 (Bruce E. Cain et al. eds., 2003) (summarizing "the neoliberal agenda" of New Public Management reforms in attempting "to apply the discipline of the market to government"); see also supra note 114 (associating TI with New Public Management).

${ }^{145}$ See Justin Longo, \#OpenData: Digital-Era Governance Thoroughbred or New Public Management Trojan Horse?, PuB. Pol'y \& Governance ReV., Spring 2011, at 38, 41-44 (noting the extent to which digital transparency ideals share those of New Public Management), available at http:// ppgr.files.wordpress.com/2011/05/longo-ostry.pdf.

146 See, e.g., NOVECK, supra note 141, at 18-20 (developing a "collaborative vision of democratic theory" and egalitarian, democratic participation via information technology), 38-44 (defining and outlining a vision of "collaborative democracy" in a "Wiki Government"); Beth Noveck, Defining Open Government, CAIRNS BLOG (Apr. 14, 2011, 12:57 PM), http://cairns.typepad.com/blog/2011/04/whatsin-a-name-open-gov-we-gov-gov-20-collaborative-government.html (blog entry posted soon after Noveck left the Obama administration, in which she defined open government as one that uses "network technology to connect the public to government and to one another informed by open data" in order to "ask[] for help with solving problems").

${ }^{147}$ For a recent summary of new governance, see Jason M. Solomon, Law and New Governance in the 21st Century Regulatory State, 86 TEX. L. REV. 819, 823-37 (2008). 
Government administrations have incorporated the movement's ideas into their practices. President Barack Obama announced soon after his January 2009 inauguration an Open Government Initiative (OGI) ${ }^{148}$ whose implementation, announced in December 2009 by Office of Management and Budget Director Peter Orszag, sought to promote "[t]he three principles of transparency, participation, and collaboration [that] form the cornerstone of an open government" through specific policies that each federal agency would implement. ${ }^{149}$ Beth Noveck, a high-profile academic advocate for digital transparency, served a key role in developing and implementing the OGI. In a blog post she co-authored on the White House's OGI blog the day after Orszag issued his memo, she promoted open government as a means to foster "collaboration between government, private industry, and the public to improve the lives of Americans in their communities," and touted the administration's early efforts to make data available to the public about emergency first responders and nutrition, and to businesses and entrepreneurs about publicly-funded technologies and patents. ${ }^{150}$ In a later interview, Noveck went so far as to disavow the use of the term "open government" as a moniker for the Obama administration's program; instead, she explained, it should have been named as it was conceived - as a collaborative, "wiki"-like recasting of the state's informational relationship with its citizens. ${ }^{151}$ The OGI, in short, would do more than simply open the government in a traditional manner-it would implement new governance at the federal level.

${ }^{148}$ See Memorandum from President Barack Obama to Heads of Exec. Dep'ts and Agencies, 74 Fed. Reg. 4685 (Jan. 26, 2009) (proclaiming the President's commitment to making government "transparent," "participatory," and "collaborative" as part of his Administration's effort to be transparent and open), available at http://www.whitehouse.gov/the_press_office/TransparencyandOpen Government/; Wendy R. Ginsberg, Cong. Research Serv., The Obama Administration's Open GOVERNMENT INITIATIVE: ISSUES FOR CONGRESS 12-26 (2011), available at http:// www.law.umaryland.edu/marshall/crsreports/crsdocuments/R41361_01282011.pdf; Paul T. Jaeger \& John Carlo Bertot, Transparency and Technological Change: Ensuring Equal and Sustained Public Access to Government Information, 27 Gov'T INFO. Q. 371, 373 (2010), available at http:// www.elsevier.com/locate/govinf/. On Noveck's role in the administration, see Daniel Terdiman, Obama's Open-Government Director Opens Up, CNET NEws (Dec. 8, 2009, 12:00 PM), http://news.cnet.com/8301-13772_3-10411479-52.html\#ixzz1LsYZuLmt.

${ }^{149}$ Memorandum from Peter R. Orszag, Dir., Office of Mgmt. and Budget, to Heads of Exec. Dep'ts and Agencies 1 (Dec. 8, 2009), available at $\mathrm{http} / /$ www.whitehouse.gov/omb/assets/memoranda_2010/m1006.pdf.

${ }^{150}$ Norm Eisen \& Beth Noveck, Why Open Government Matters, Open Gov'T InITIATIVE BloG (Dec. 9, 2009, 3:16 PM), http://www.whitehouse.gov/blog/2009/12/09/why-open-government-matters.

${ }^{151}$ JEFF JARVIS, PUBLIC PARTS 198-99 (2011). 
Digital transparency's promise and application are on even clearer display in those American municipalities that have aggressively adopted information technologies to make their data available. ${ }^{152}$ A number of larger cities with strong software development industries have encouraged the use of their data for development by private firms ${ }^{153}$-indeed, the City of New York and its Metropolitan Transit Authority have even sponsored contests with cash prizes for software developers to create apps using government data sets. ${ }^{154}$ New York has created the position of Chief Digital Officer whose job is to "improv[e] communication with residents and businesses by enhancing government transparency and working closely with digital media." ${ }^{155}$ Such positions, as well as more senior positions of municipal information or technology officer, have been given new responsibilities to encourage communication and collaboration with the public through web portals and social media. ${ }^{156}$ In the first months of her tenure as New York's Chief Digital Officer, Rachel Sterne discussed with technology companies "ways to use their platforms to showcase the work of city agencies" and unveiled The Daily Pothole, a blog that reports on street repairs. ${ }^{157}$ Filling potholes is not the only local-government service that information technology can assist. Drivers in some cities can use applications on their smart phones to learn of

152 The best survey of digital transparency at the municipal level in the U.S. is Shkabatur, supra note 143 , at $1443-64$.

${ }^{153}$ See Claire Cain Miller, Local Governments Offer Data to Software Tinkerers, N.Y. TIMES, Dec. 7, 2009, at B1, available at http://www.nytimes.com/2009/12/07/technology/internet/07cities.html.

${ }^{154}$ Sarah Kessler, App Quest Contest Challenges Developers To Create Apps Using NYC Data, MASHABLE (July 12, 2011), http://mashable.com/2011/07/12/mta-app-contest/.

${ }^{155}$ The Mayor's Office of Media and Entertainment Announces the Hiring of Rachel Sterne as New York City's First Chief Digital Officer, NYC.GOv, http://www.nyc.gov/html/media/html/news/cto announcement.shtml (last visited Nov. 9, 2011); Patrick McGeehan, City Picks Entrepreneur to Lead Digital Efforts, CiTY Room Blog (Jan. 24, 2011, 5:24 PM), http://cityroom.blogs.nytimes.com/2011/ 01/24/city-picks-entrepreneur-to-lead-digital-efforts/.

${ }^{156}$ See Merrill Douglas, G7: CIOs From Seven Big-Cities Work Together to Develop Open-Source IT Solutions, GOV'T TECH. (Oct. 18, 2010), http://www.govtech.com/e-government/G7-Big-City-CIOsWork-to-Develop-Open-Source-IT-Solutions.html. One of the most prominent such CIOs is Chris Vein, who in 2011 moved from serving as San Francisco's Chief Information Officer to the White House as Deputy Chief Technology Officer for Innovation. See Adam Conner, Connecting with Chris Vein: City Hall Technologist, FACEBOOK BLOG (July 19, 2010, 9:31 AM), http://www.facebook.com/blog .php?post=408323042130; Nick Judd, White House Taps Top City CIO to Replace Beth Noveck as Deputy CTO for Innovation, TeCH PRESIDENT Blog (Feb.28, 2011, 11:15 AM), http:// techpresident.com/blog-entry/white-house-taps-top-city-cio-replace-beth-noveck-deputy-cto-innovation.

${ }^{157}$ Javier C. Hernadez, A Digital Matchmaker for the City and Its Public, N.Y. TiMES, July 31, 2011, at MB1. 
available parking spots, for example, while the cities, in turn, can use the data collected about the demand for parking on certain streets and in certain neighborhoods to set variable pricing. ${ }^{158}$ Perhaps unsurprisingly, San Francisco appears to be in the lead in municipal digital transparency as a matter of practice and law: not only does it boast DataSF, a web portal that serves as a clearinghouse for its data sets, ${ }^{159}$ but it is also the first city to enact an open-data ordinance requiring city departments to make their data sets available to the public. ${ }^{160}$

Digital-transparency advocates thus promise more than simply a reformed state. At their most exuberant, they assert that online collaboration and data flows between public and private parties can shrink the state, if not make it wither away altogether. ${ }^{161}$ An "open civic system" carried over and through public and private networks allows everyone, from app designers to the wisest of crowds, to solve the problems that bureaucrats formerly struggled with behind the government's closed doors. ${ }^{162}$ In the traditional, modern technocratic conception, government agencies and officials merely gather, organize, and release information. But now, Tim O'Reilly argues, the state should no longer be viewed as the "first mover of civic action" but instead as a "platform" and "the manager of a marketplace" for private and government interaction. ${ }^{163}$ It might continue to provide key public services, but in doing so it must gather and release data about its performance; it can be involved

${ }^{158}$ See Sarah Kessler, How Smarter Parking Technology Will Reduce Traffic Congestion, MASHABLE (Apr. 13, 2011), http://mashable.com/2011/04/13/smart-parking-tech/; THE DAILY POTHOLE, http:// thedailypothole.tumblr.com/ (last visited July 21, 2012).

${ }^{159}$ DataSF - Liberating City Data, DATASF, http://datasf.org/ (last visited July 21, 2012).

160 S.F., CAL., Administrative CODE § 22D.2 (2011), available at http://www.amlegal.com/nxt/ gateway.dll/California/administrative/administrativecode? $\mathrm{f}=$ templates $\$ \mathrm{fn}=$ altmain-nf.htm $\$ 3.0 \quad$ (follow "Contents" hyperlink on left; then follow "Chapter 22D: Open Source Policy" hyperlink); E.B. Boyd, San Francisco Passes First Open Data Law, FAST COMPANY (Nov. 9, 2010), http:// www.fastcompany.com/1701410/san-francisco-passes-first-open-data-law.

${ }^{161}$ See, e.g., Kevin Kelly, What Technology Wants 317 (2010) (arguing that digital "technologies of collaboration," with their great "powers of socialization-sharing, cooperation, collaboration, openness, and transparency" enable the triumph of the free market over centralized state planning). This ideal is not new among Internet futurists and advocates. See FLICHY, supra note 128, at 155-77 (describing the libertarian vision of a limited state among early cyberspace proponents). The conflict between the collective and individualist strains of digital transparency is akin to the similar conflict in the romantic ideals of the open source movement. See ThOMAs StreEter, The Net EfFECT 154-67 (2011).

162 John Geraci, The Four Pillars of an Open Civic System, O’ReILly Radar (June 15, 2009), http://radar.oreilly.com/2009/06/the-four-pillars-of-an-open-ci.html.

${ }^{163}$ O'Reilly, supra note 131 , at 12-13. 
in the creation of public goods, but only by building or initiating capital-intensive infrastructure (like information highways) that are unlikely to be provided in sufficient quantities by the market. ${ }^{164}$ Then the state must get out of the way, serving only as a conduit of information by which individual entrepreneurs can make government data available and useful via the web, ${ }^{165}$ bloggers and websites can "crowdsource" government data to make sense out of it, ${ }^{166}$ and software designers can "mash-up" government information in order to make it more userfriendly for mobile computing devices like smart phones. ${ }^{167}$ In its collaborative and shrunken guises, the transformed state will serve as an adjunct to market activity that exists only to distribute information as a public good and to stimulate private economic and civic development. ${ }^{168}$

Significant by its absence in this conception is government's more traditional, broader police-power authority to enforce laws and promulgate and enforce regulations, as well as its role in redistributing wealth. The digital state provides services and information; it eschews coercion and paternalism in favor of collaboration and negotiation. ${ }^{169}$ Whereas the traditional FOI approach seeks to open a window onto state activity, allowing the public to peer in, digital transparency offers to plug the state into existing data flows, connecting government, reconceived largely as a data repository, into part of a seamless web of information. ${ }^{170}$ The FOI and anti-corruption movements seek to reform the state and its practices by opening them to public view; digital transparency promises to transform the state by redefining its role within a networked economy and society.

${ }^{164}$ Id. at $12-15$.

165 See, e.g., Nancy Scola, Washington's I.T. Guy, Am. ProsPeCt, July/Aug. 2010, at 21, 21-24 (describing the decades-long efforts of Carl Malamud to get government information online).

${ }^{166}$ See SIFRY, supra note 127 , at $77-82$.

${ }^{167}$ Ellen S. Miller, Using the Web for Greater Government Openness and Transparency, Bus. OF Gov'T, Fall/Winter 2009, at 50, 51-52, available at http://www.businessofgovernment.org; Douglas McGray, iGov: How Geeks are Opening Up Government on the Web, ATLANTIC, Jan.-Feb. 2009, at 36.

${ }^{168}$ On the notion of information as a public good, see CASS SUNSTEIN, REPUBLIC.COM 2.0, at 107-09 (2007).

${ }^{169}$ On the relationship between digital technology romanticism and neoliberal ideals about the state's withering away as an agent of regulation and redistribution, see Thomas Streeter, "That Deep Romantic Chasm": Libertarianism, Neoliberalism, and the Computer Culture, in COMMUNICATION, CitizenshiP, AND Social POLICY 49 (Andrew Calabrese \& Jean-Claude Burgelman eds., 1999).

${ }^{170}$ See SIFRY, supra note 127, at 102 ("In this understanding, the relationship between governments and their constituents is a two-way street, and data is the road that connects them.”). 
Alongside information technology's promise to transform the state is the related assumption that technology will transform the public by expanding citizens' ability to receive data from the state and push data to it. In the digital present, citizens can finally act as informed users of government services and active participants in democratic politics. The blogger and journalist Jeff Jarvis imagines a world in which everyone creates "personal political pages" where they discuss their own beliefs and commitments, "manage" their "relationship" with politicians and government officials, and have their pages aggregated by Google ("the polling place that never closes"). This, in turn, will allow activist networks to form and participate more effectively in politics and government. ${ }^{171}$ For Yochai Benkler, the networked information environment has produced "a cultural shift in selfperception, from passive couch potato to active participant in collaborative practices for making one's own information universe, [which] opens the opportunity for a more robust, sustainable level of involvement by citizens in the governance of their society." ${ }^{172}$ Plugged into the informational network, the state is now available in unmediated form for contemporary citizens who are no longer dependent upon the commercial press' institutional gate-keeping role. Private websites can sort, organize, and make data useful for the public, ${ }^{173}$ first in the shadow of and perhaps ultimately in the absence of any authoritative press that collects information and educates the public. Indeed, a more competitive market of entrepreneurial data managers, programmers, website authors, and crowdsourcing masses can mash up and process information that the public finds more useful to its needs and preferences. Digital transparency promises a future that can develop participatory, collaborative, and inquisitive "netizens" who are capable of self-rule out of the bored, passive, and cynical apolitical masses who only imagine they ruled the opaque state of the twentieth century.

\section{B. The Limits of the Technological Fix}

Digital transparency builds on a number of contested assumptions about information's direct effects. ${ }^{174}$ Information technology's advocates have long envisioned a technological sublime: "Every important new technology," Philip

\footnotetext{
${ }^{171}$ Jeff Jarvis, The Ethics of Openness, in REBOOTING AMERICA: IDEAS FOR REDESIGNING AMERICAN DEMOCRACY FOR THE INTERNET AGE 215, 218-20 (Allison Fine et al. eds., 2008).

172 Yochai Benkler, Participation as Sustainable Cooperation in Pursuit of Public Goals, in ReBooting AMERICA, supra note 170 , at 48, 52-53.

${ }^{173}$ David Robinson et al., Government Data and the Invisible Hand, 11 YALE J.L. \& TECH. 160 (2009).

${ }^{174}$ Fenster, supra note 3, at 927-33. For a vivid, articulate description of the conflicts over information theory, see JAMES GLEICK, THE INFORMATION 413-26 (2011).
} 
Agre explained, "creates an imaginative vacuum, and time and again this is the sort of thing that flows into it: tropes of transcendental escape, utopian perfection, discontinuous change, communitarian intimacy, everlasting peace, and boundless prosperity." "175 Following this long-established tradition, digital transparency heralds information technology as the cure to our opaque, bloated state and disinterested, alienated masses. Notwithstanding the movement's noteworthy successes at the federal and local levels, however, it is unclear precisely how the state and public have been or will soon be transformed by the technological and administrative revolution advocates forecast. Information's fast and cheap distribution in digital form does not necessarily translate into egalitarianism and democracy, civic-mindedness and wealth creation, or knowledge and understanding. ${ }^{176}$ No doubt many technologically savvy users of government services are willing and able to take advantage of new data flows to enhance their lives and gain knowledge that informs their voting and political participation, but studies to date have tended to show that use patterns of online government resources reflect age, class, and educational differences, and that the heaviest users are the youngest, wealthiest, and most educated. ${ }^{177}$ Furthermore, while it is unclear

\footnotetext{
${ }^{175}$ Philip Agre, Cyberspace as American Culture, 11 SCI. AS Culture 171, 173-74 (2002); see also DAVID F. NoBle, The Religion OF TECHNOLOGY 158-60 (1997) (describing the quasi-religious claims made by cyberspace proponents). On the history of American preoccupations with technology's utopian possibilities, see generally DAVID E. NYE, AMERICAN TECHNOLOGICAL SUblime (1994) and HowARD P. Segal, Technological Utopianism in American Culture (1985). For a critique of this tradition, with particular emphasis on technology's relationship to exploitative capital, see DAVID F. NOBLE, America By Design: Science, TeChNOlogy, AND the Rise of CoRporate CAPITAlism (1977).

${ }^{176}$ For examples of critics and skeptics of digital democracy, see MATthEW HindMAN, THE MYth OF Digital Democracy 12-19 (2009); Evgeny Morozov, Net Delusion 239-41 (2011); Sunstein, supra note 168, at 212-23. For examples of sympathetic authors who express skepticism about digital transparency, see FUnG, GRAHAM \& WeIL, supra note 17, at 33-34; MARY GRAHAM, DEMOCRACY BY DisClOSURE 140-42 (2002). As David Sholle has noted, advocacy surrounding information technology frequently views information as a content-less, decontextualized thing, neglecting content and the complex, context-contingent communicative process in which meaning is produced. See David Sholle, What Is Information? The Flow of Bits and the Control of Chaos, in DEMOCRACY AND New MEDIA 343 (Henry Jenkins \& David Thorburn eds., 2003). As Roland Barthes explained, the notion that language is merely instrumental, neutral, and above all transparent is itself a product of the emergence of modern science, religious argument, and empiricist and rationalist ideals. See Roland BARTHES, THE RUSTLE OF LANGUAGE 4 (Richard Howard trans., 1986).

177 See Aaron Smith, Pew Internet \& Am. Life Project Report, Government Online: The internet Gives Citizens New Paths to Government Services and Information (2010), available at $\mathrm{http} / / / \mathrm{www}$. pewinternet.org/ /media//Files/Reports/2010/PIP_Government_Online_2010_ with_topline.pdf; Michael X. Delli Carpini \& Scott Keeter, The Internet and an Informed Citizenry, in The CIVIC WeB 129, 139-45 (David M. Anderson \& Michael Cornfield eds., 2003); Samuel J. Best \& Brian S. Krueger, Analyzing the Representativeness of Internet Political Participation, 27 POL. BEHAV.
} 
whether the public is incrementally more informed about government and its performance than in the pre-digital era, dissatisfaction with the state appears to run at least as high as in analog times. The wired general public has not (yet, at least) been transformed into the satisfied, enlightened, collaborative polis that digital transparency promises.

Nor is it clear that information technology can tame the institutional complexity and bureaucratic resistance that complicate efforts to reveal the state to the public. The modern state, for good and bad reasons, is composed of multiple, overlapping organizational layers that extend within and across jurisdictions and space, ${ }^{178}$ smoothing out its striated institutions will require more than imagining it as a data repository and single entity capable of open collaboration and then offering a technological fix through access to government data and open source code. ${ }^{179}$ Again, there is no doubt that governments, NGOs, and commercial entities have made great inroads into making government information available and useful, but one would be hard-pressed at present to conclude that these effects have created a new form of government or new age of governance. The Obama administration's efforts illustrate this well: the very digital advocates who cheered the announcement of its OGI have complained that its changes have been incremental rather than revolutionary and that its implementation has frequently been disappointing. ${ }^{180}$ Perhaps the disappointing results have come from a failure of administrative will or strategy, or demonstrate the entrenchment of existing practices, or the necessary resources were not available, or digital transparency

183, 185-86 (2005); Kay Lehman Schlozman, Sidney Verba \& Henry E. Brady, Weapon of the Strong? Participatory Inequality and the Internet, 8 PERSP. ON POL. 487 (2010).

178 On how the state's organizational and geographical complexity makes transparency difficult to accomplish, see Fenster, Seeing the State, supra note 3, at 632-36.

${ }^{179}$ For an illustration of how the bureaucratic empire fights back, see What Transparency Means to Feds, NeXTGOV (Apr. 1, 2009), http://www.nextgov.com/nextgov/ng_20090401_5914.php (polling government managers and finding a mixed response to the Obama administration's Open Government Initiative).

${ }^{180}$ Jaeger \& Bertot, supra note 148, at 373-75; Open Government Directive: Year One, Success and Setbacks on the Way to a More Open Government, Sunlight Found. (Dec. 7, 2010), http:// sunlightfoundation.com/press/releases/2010/12/07/open-government-directive-year-one/ ("The [Obama] administration has to give stronger direction and urge the agencies to move forward if the promise of an open government is to be realized."). More traditional transparency advocates, such as the National Security Archive, have expressed similar disappointment in the administration's more traditional disclosure practices under the FOIA. See NaT'L SEC. ARChive, Glass Half Full: 2011 Knight Open GOVERNMENT SURVEY FINDS FREEDOM OF INFORMATION CHANGE (2011), available at http:// www.gwu.edu/ nsarchiv/NSAEBB/NSAEBB338/KnightOpenGovtSurvey2011.pdf (reporting on the mixed results of an audit of federal agencies' compliance with FOIA). 
U N I V E R S I T Y O F P I T T S B U R G H L A W R E V I E W

PAGE

became a lower priority as the administration faced more difficult and important challenges; perhaps it was never intended to be an especially high priority. For whatever reason, digital transparency has not proven its inevitable triumph over the federal bureaucracy, even within an administration and program that appeared so promising. At the same time, the Obama administration's achievements are fragile - in the present the OGI relies on the current administration's willingness to invest human and capital resources on its development, and it may be abandoned or reduced by future presidents. ${ }^{181}$ Put simply, the digital-transparency revolution, should it occur, will be a consequence of both policy and politics. It will continue to be subject to these very human, imperfect processes, rather than bloom inexorably through some ahistorical, sublime technological force.

\section{Conclusion}

Digital-transparency advocates claim that the revolution in information technology has already freed and will only further free the state's data to the public, for whom it will be packaged by public entities, private entrepreneurs, and wise, wired crowds so that it can be available for everyday use, political action, and commercial advantage. The basic logic underlying this process parallels those described in the rights-based FOI movement and the contemporary digital movement: the state is a repository of information (recast now as data) that must be freed from its clutches and made available to the public, although by means of code and bits rather than law; and once information (or data) is made "free" (or flows through a network), it will necessarily have transformative, positive effects on politics and society. ${ }^{182}$ In this regard, they both share civic ideals that date back at least to the Progressive Era, when to be a good citizen required one to be well informed. ${ }^{183}$ The happy ending that digital transparency's policy story offers also parallels Transparency International's prescription: that the transparent administrative state will operate more efficiently and inspire the development of new markets for investment and widespread economic development.

Nevertheless, digital transparency relies on a quite different set of tools to secure a transparent state. Information technology, and developers that innovatively apply it, will better fix the state than legal rights enforced by state institutions and

\footnotetext{
${ }^{181}$ A Congressional Research Service report on the OGI provides a mixed review of the administration's performance and identifies, without any recommendation, the issue of whether Congress should codify any of the OGI's policies. See GINSBERG, supra note 148, at 27-28.

${ }^{182}$ Fenster, supra note 3, at 895-902.

${ }^{183}$ Michael Schudson, Click Here for Democracy: A History and Critique of an Information-Based Model of Citizenship, in DEMOCRACY AND New MEDIA, supra note 176, at 49, 57.
} 
the press or the transnational institutional watchdogs that pressure state institutions to conform to administrative and legal norms. More significantly, the classic legal approach views the rights and duties that open government laws create as acting neutrally upon the state, whose functions and operations would not necessarily change-though they would improve-due to the greater exposure and accountability that an enforceable right to know allows. The digital-transparency movement, by contrast, imagines a state that is defined by its data and the flow of information to and from it rather than by its actions, that is more immediately responsive to the public and allows extensive citizen participation and collaboration, and that provides a "platform" for government services and for the provision of public informational goods. The staunchest of the digital advocates appear ready to abandon the standard post-war model of the regulatory welfare state, with its overly paternalistic and invasive bureaucracy, and replace it with one that does little more than collect and enable the aggregation of data for public use and benefit or that operates as an open-source government through which citizens act directly with and upon officials to rule themselves. And whereas the FOI and NGO-based approaches envision a public that pays attention to the state and holds it accountable, digital-transparency advocates envision a thoroughly active public that is fully capable of engaging in effective popular democracy. Having subverted the intermediaries of the institutional press, having rendered an independent judiciary and transnational NGOs (themselves now networked with state actors and IFIs) largely unnecessary, and having shrunk the state and left it smaller and with a humbler role, digital transparency assumes in their place the emergence of a public that will act as wired "netizens" (and decidedly not mere couch potatoes).

\section{The Vigilante Fix: Wikileaks ANd TransParency}

Along with its offshoots and followers, ${ }^{184}$ WikiLeaks offers a distinct transparency agent: an organization and media outlet with the means to receive important digital files that shed light on government actions, distribute the files widely in electronic form, and protect its sources' anonymity. ${ }^{185}$ After launching in

\footnotetext{
${ }^{184}$ See infra note 193.

${ }^{185}$ The full WikiLeaks story is complex and still developing as this article is being written. For thorough and more fully sourced accounts, on which this section will depend, see Benkler, supra note 16; Mark Fenster, Disclosure's Effects: WikiLeaks and Transparency, 97 IOWA L. REV. 753 (2012), available at http://www.uiowa.edu/ ilr/issues/ILR_97-3_Fenster.pdf. For additional background information, see

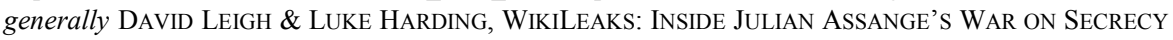
(2011); Greg Mitchell, The Age OF WikiLeaKs (2011); Alasdair Roberts, WikiLeaks: The Illusion of Transparency, 78 INT'L REV. ADMIN. SCI. 116 (2012); Molly Sauter, WikiLeaks FAQ, THE FUTURE OF THE INTERNET AND HOW TO STOP IT BLOG (Dec. 7, 2010), http://futureoftheinternet.org/wikileakscable-faq; WikiLeaks, WIKIPEDIA, http://en.wikipedia.org/wiki/WikiLeaks (last updated July 2011). In
} 
U N I V E R S I T Y O F P I T T S B U R G H L A W R E V I E W

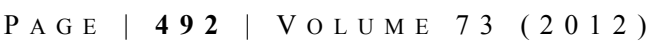

2006 and enjoying some success in releasing documents that proved embarrassing to some governments, ${ }^{186}$ the site became most famous in the U.S. in 2010 when it began to release a massive cache of classified files that had been stolen from the Departments of Defense and State, ${ }^{187}$ allegedly by a serviceman whose security clearance and computer skills enabled him to download the materials from a military file server. ${ }^{188}$ Although none was classified above "secret," documents were unavailable to the public prior to their release by WikiLeaks. ${ }^{190}$ Commentators have debated the extent of the documents' significance and how much they have revealed, but there can be no question that WikiLeaks's disclosures

addition to government documents, WikiLeaks also receives and distributes documents purloined from private corporations, but I will focus here only on the government documents it has released.

${ }^{186}$ WikiLeaks's early releases of documents included evidence of corruption in the Kenyan government; operation manuals of the Guantanamo Bay detention camp; secret manuals from the Church of Scientology; and documents that revealed self-dealing by the owners of Kaupthing Bank, the bank whose collapse hastened Iceland's financial downfall. See LEIGH \& HARDING, supra note 185, at 57-64; Manfred Goetzke, WikiLeaks Website Offers Promising Outlet for Fighting Corruption, DeUTSCHE WeLLE (Nov. 26, 2009), http://www.dw-world.de/dw/article/0,,4930880,00.html.

${ }^{187}$ Benkler, supra note 16 , at 321-30.

${ }^{188}$ Mitchell, supra note 185, at 38-50; Alex Altman, Afghan Leaks: Is the U.S. Keeping Too Many Secrets?, TIME, July 30, 2010, http://www.time.com/time/nation/article/0,8599,2007224,00.html; Ginger Thompson, Early Struggles of Soldier Charged in Leak Case, N.Y. TIMES, Aug. 9, 2010, at A1.

${ }^{189}$ Most of the documents that composed the Afghanistan and Iraq "War Logs" were classified "secret." Piecing Together the Reports, and Deciding What to Publish, N.Y. Times, July 26, 2010, at A8, available at http://www.nytimes.com/2010/07/26/world/26editors-note.html; Scott Stewart, WikiLeaks and the Culture of Classification, StratFor GlOBAL InTEL. (Oct. 28, 2010), http://www.stratfor.com/weekly/20101027_wikileaks_and_culture_classification. Of the more than 250,000 diplomatic cables WikiLeaks obtained, approximately 11,000 were classified "secret," 4000 were classified "secret" and "noforn" (that is, not to be shared with a foreign government), and 9000 were classified "noforn." Scott Shane \& Andrew Lehren, Leaked Cables Offer Raw Look at U.S. Diplomacy, N.Y. TimeS, Nov.29, 2010, at A1, available at http://www.nytimes.com/2010/11/29/ world/29cables.html. See also What Do the Diplomatic Cables Really Tell Us?, DER SPIEGEL (Nov. 28, 2010), http://www.spiegel.de/international/world/0,1518,731441,00.html (giving slightly different figures from those reported by The New York Times).

${ }^{190}$ See Daniel W. Drezner, Why WikiLeaks Is Bad for Scholars, CHRON. Higher ED., Dec. 5, 2010, $\mathrm{http} / /$ chronicle.com/article/Why-WikiLeaks-Is-Bad-for/125628/ (characterizing diplomatic cables as documents that would have been unavailable to academics for decades); Dan Murphy, WikiLeaks Releases Video Depicting U.S. Forces Killing of Two Reuters Journalists in Iraq, CHRISTIAN SCI. MONITOR (Apr. 5, 2010), http://www.csmonitor.com/World/Global-News/2010/0405/Wikileaksreleases-video-depicting-US-forces-killing-of-two-Reuters-journalists-in-Iraq (noting that the Collateral Murder video showed an attack about which Reuters had unsuccessfully sought information through the Freedom of Information Act). 
have at least marginally increased public knowledge about recent American military campaigns and the nation's diplomatic relations with other countries. ${ }^{191}$

The organization itself is small and somewhat anonymous (besides the celebrity status of its founder, Julian Assange), but it presents itself as a transnational NGO campaigning to change the political order and society. As its website declares,

WikiLeaks is an independent global group of people with a long standing dedication to the idea of a free press and the improved transparency in society that comes from this....

The broader principles on which our work is based are the defence of freedom of speech and media publishing, the improvement of our common historical record and the support of the rights of all people to create new history. We derive these principles from the Universal Declaration of Human Rights. ${ }^{192}$

Embracing the conception of government information as a human right while exploiting information technology both to obtain and distribute classified documents, WikiLeaks combines elements of both the rights-based and digitaltransparency advocacy movements.

\section{A. Vigilante Transparency as Rights Protector and Enforcer}

WikiLeaks has played two significant roles as an advocate for transparency. First, by establishing its own powerful brand identity as a technologically sophisticated service capable of distributing purloined data anonymously, it has proven the viability of an anonymous, online leaking site as a model for others to follow. Numerous sites, both independent, non-profit ones and some proposed by established newspapers, have announced plans to do so. ${ }^{193}$ Second, its extralegal

${ }^{191}$ See Fenster, supra note 185, at 790-807 (summarizing arguments made by WikiLeaks critics and proponents on the relative significance of the site's disclosures, and attempting to discern their wider impact on the general public).

${ }^{192}$ About: What Is WikiLeaks?, WIKILEAKs, http://wikileaks.org/About.html (last visited July 21, 2012).

${ }^{193}$ A disgruntled former WikiLeaks member, Daniel Domscheit-Berg, has launched another rival site, while The New York Times, WikiLeaks's U.S. journalistic collaborator (with which it has a stormy relationship), may establish a competing site that would allow whistleblowers to anonymously pass documents to the newspaper. See Michael Calderone, NY Times Considers Creating an "EZ Pass Lane for Leakers," YAHOO! NEWS BLOG (Jan. 25, 2010, 8:38 AM), http://news.yahoo.com/blogs/cutline/nytimes-considers-creating-ez-pass-lane-leakers-20110125-053811-988.html; A Swarm of Leaks, ECONOMIST, Dec. 9, 2010, at 72, available at http://www.economist.com/node/17674089?story_id= 17674089; Frank Jordans, Openleaks, WikiLeaks Rival, Launches New Secret-Spilling Site, HuFFINGTON POST (Jan. 28, 2011, 10:31 AM), http://www.huffingtonpost.com/2011/01/28/openleaks- 
(and possibly illegal) disclosure of illegally obtained government documents implicitly challenges government information security policies, a challenge that Assange has made explicit in his writings and interviews. ${ }^{194}$ Like digital and anticorruption transparency advocates, Assange has identified an information asymmetry and hoarding problem, a transparency fix, and a political objective: state secrecy can be defeated by whistleblowers and hackers who, through the medium of WikiLeaks, will leave in their wake a smaller, chastened, fully visible state.

The issue WikiLeaks has confronted is the same that motivated the original FOI movement: state actors' under-enforcement or blatant disregard of the public's basic human right to view government information. ${ }^{195}$ The site describes its project in broad, world-historical terms:

Article 19 [of the Universal Declaration of Human Rights] inspires the work of our journalists and other volunteers. It states that everyone has the right to freedom of opinion and expression; this right includes freedom to hold opinions without interference and to seek, receive and impart information and ideas through any media and regardless of frontiers. We agree, and we seek to uphold this and the other Articles of the Declaration. ${ }^{196}$

WikiLeaks enforces this right, it claims, by disclosing facts - the raw documents that the state attempts to suppress. It does so through the "scientific journalism" it

wikileaks-rival_0_n_815309.html. For accounts of other sites that have either adopted or adapted the WikiLeaks model, or that have announced plans to do so, see Benkler supra note 16, at 350; Fenster, supra note 184 , at 759-60.

${ }^{194}$ See, e.g., About: What Is WikiLeaks?, supra note 192 (defining and defending "principled leaking" as a means to resist and challenge "secrecy laws [that] are being used to keep the public ignorant of gross dishonesty practised by their own government"); Bivol, 2011-05-01 Julian Assange: "I Believe in the Right to Communicate and the Inviolability of History,” WL CENTRAL (May 1, 2011), http:// wlcentral.org/node/1727 (quoting Assange interview with Bulgarian investigative journalism website in which he states, "Cablegate was not born from the citizen's rights to access information: if this was the case Cablegate would have come from FOIA requests. Rather it was born from people who presumably worked for the US government feeling the information they saw showed wrongdoing that the public should know about.").

${ }^{195}$ Hans Ulrich Obrist, In Conversation with Julian Assange, Part II, 26 E-FLUX J., June 2011, at 7, available at http://worker01.e-flux.com/pdf/article_238.pdf [hereinafter Obrist, Conversation II] (claiming that WikiLeaks can enforce the human right to know, the right to speak, and, above all, the right to communicate information).

${ }^{196}$ About: What Is WikiLeaks?, supra note 192. 
claims to practice, which proves the truth of an objective news story by allowing readers "to click online to see the original document it is based on. That way you can judge for yourself: Is the story true? Did the journalist report it accurately?"197

Although it shares with the legal-rights approach the claim that access to government information is so central to democracy that it must receive legal protection, the site has little faith in the state's willingness to disclose its secrets and even to obey its own laws. Instead, WikiLeaks claims to advance popular democracy against despotic central authorities by obtaining and distributing the sovereign's information:

Today, with authoritarian governments in power in much of the world, increasing authoritarian tendencies in democratic governments, and increasing amounts of power vested in unaccountable corporations, the need for openness and transparency is greater than ever. WikiLeaks interest is the revelation of the truth [sic]. Unlike the covert activities of state intelligence agencies, as a media publisher WikiLeaks relies upon the power of overt fact to enable and empower citizens to bring feared and corrupt governments and corporations to justice. ${ }^{198}$

The press interest groups and activists in the post-war period criticized state secrecy because they feared its use as a means to hide corrupt and potentially abusive government. They assumed that the state could serve as the institutional basis for reform. Working more than fifty years after the FOI movement began, WikiLeaks rejects political and legal reform in favor of active opposition to the state.

For WikiLeaks, technology, unlike law, can trump the power and privilege of authoritarian governments and the authoritarian "tendencies" of putatively democratic states. "As a result of technical advances," WikiLeaks declares, "particularly the internet and cryptography," it can receive and distribute state secrets while it lowers if not eliminates risk to itself, its readers, and, most importantly, its sources. ${ }^{199}$ This looks superficially like a technological fix to secrecy akin to that proposed by the digital-transparency movement, and the site appears to share technologists' utopian sentiments about a networked future.

\footnotetext{
${ }^{197}$ Julian Assange, Don't Shoot Messenger for Revealing Uncomfortable Truths, AUSTRALIAN, Dec. 8, 2010, http://www.theaustralian.com.au/in-depth/wikileaks/dont-shoot-messenger-for-revealinguncomfortable-truths/story-fn775xjq-1225967241332.

${ }^{198}$ About: What Is WikiLeaks?, supra note 192.

${ }^{199} I d$.
} 
WikiLeaks does not share the technologists' sunny view of social media and collaboration, however, and Assange himself appears as distrustful of the market and of corporate entities as he is of the state. ${ }^{200}$ He has explicitly expressed disdain for the very collaborative technological mechanisms that the digital-transparency advocates embrace - blogs, crowdsourcing, and the like - in the distribution of information. ${ }^{201}$ The site had at first depended on the blogosphere and online communities to publicize its releases and provide further investigation into their significance and context - a hope that proved unavailing. ${ }^{202}$ As a result, the site began to collaborate directly with major international newspapers for its Afghanistan, State Department, and Guantanamo releases, embracing precisely the old media whose predecessors sponsored the first wave of transparency advocacy and whose rapidly diminishing status as information gatekeeper the digital world was supposed to render obsolete. ${ }^{203}$

In combining but also rejecting elements of the rights-based and digital approaches to transparency, while collaborating with mainstream newspapers and declaring its radical distrust of the state and other concentrated sources of power, WikiLeaks articulates and advocates a complex, conflicting conception of transparency. On the one hand, it seems to pursue the traditional goal of revealing the state to the public - not only to the citizens who can hold the state directly accountable but also to everyone who is able to "see evidence of the truth." 204 "[O]ur sort of modus operandi behind our whole organization," Assange has said, "is to get out suppressed information into the public, where the press and the public

\footnotetext{
${ }^{200}$ Fenster, supra note 185 , at 780.

201 See Julian Assange, The Hidden Curse of Thomas Paine, GuERNICA, Apr. 29, 2008, http:// www.guernicamag.com/blog/571/the_hidden_curse_of_thomas_pai/; Aaron Bady, Julian Assange in Berkeley, ZunGUZUnGU (Dec. 12, 2010, 5:53 PM), http://zunguzungu.wordpress.com/2010/12/12/ julian-assange-in-berkeley/ (quoting Assange's comments in an academic forum in which he complained that bloggers and the like "don't give a fuck about the material" and write in order to speak to and gain status with peers, not because of their inherent interest in the material or willingness to investigate it further).

${ }^{202}$ See WikiLeaks: Big Picture, WIKILEAKs, http://wikileaks.org/wiki/WikiLeaks:Big_picture (last visited July 22, 2012).

${ }^{203}$ See generally LEIGH \& HARDING, supra note 185, at 110-15 (describing the negotiated agreements between WikiLeaks and its newspaper partners to redact documents); Benkler, supra note 16, at 323-24 (summarizing the WikiLeaks releases and describing the site's relationship with the established print news media).

${ }^{204}$ About: What Is WikiLeaks?, supra note 192.
} 
and our nation's politics can work on it to produce better outcomes." ${ }^{205}$ All of the movements discussed above share this general assumption and ideal: more information leads to a more visible, functional, and authentically democratic state. And like the others, WikiLeaks can claim at least some success. Its recent military and diplomatic disclosures from the U.S. might only have marginally affected American politics and government policy, ${ }^{206}$ but the documents it has released have been distributed globally and seem to have affected countries discussed in the State Department cables. ${ }^{207}$ Viewed this way, WikiLeaks appears to offer an institutional mechanism for democratic reform, like the earlier transparency advocacy movements.

But WikiLeaks also aspires to transform the state in more radical ways. Its critique of the state's tendency towards secrecy, as well as Assange's formative years in the "cypherpunk" community and his pre-2010 writings, bespeak a political program that views disclosure primarily as a means to discipline and limit the modern state's authority over its subjects and its dealings with other nations. ${ }^{208}$ One of Assange's essays, posted online in the period just prior to WikiLeaks' launch, sets forth his justification for and theory of deploying transparency as an almost revolutionary weapon against what he described as the pervasively autocratic, secretive nature of contemporary states. ${ }^{209}$ When faced with the threat

205 Julian Assange on WikiLeaks, War and Resisting Government Crackdown, DEMOCRACY NOW! (Dec. 31, 2010), http://www.democracynow.org/2010/12/31/julian_assange_on_wikileaks_war_and; see also Time's Julian Assange Interview: Full Transcript/Audio, TIME (Dec. 1, 2010), http:// www.time.com/time/world/article/0,8599,2034040,00.html (claiming that transparency can "achieve a more just society" by allowing a more knowledgeable, engaged public to oppose "abusive plans or behavior").

${ }^{206}$ See Roberts, supra note 185, at 125-28 (noting that WikiLeaks has had minimal effects in the U.S.).

${ }^{207}$ See generally Fenster, supra note 185 (summarizing claims about external effects of WikiLeaks's State Department releases on revolutions in North Africa).

${ }^{208}$ The best resource for information about Assange's early career as a hacker and "cypherpunk," and the development of WikiLeaks is Robert Manne, The Cypherpunk Revolutionary, MonTHLY, Mar. 2011, http://www.themonthly.com.au/julian-assange-cypherpunk-revolutionary-robert-manne-3081? page $=1 \% 2 \mathrm{C} 3 \&$ destination $=$.

209 JULIAN ASSANGE, CONSPIRACY AS GOVERNANCE (2006), available at http://cryptome.org/0002/jaconspiracies.pdf. For fuller descriptions of the radical strain in Assange's writings, see Aaron Bady, Julian Assange and the Computer Conspiracy; "To Destroy This Invisible Government," ZunguZungu (Nov. 29, 2010, 9:05 AM), http://zunguzungu.wordpress.com/2010/11/29/julian-assange-and-thecomputer-conspiracy-“to-destroy-this-invisible-government"/; Fenster, supra note 185, at 774-82; Peter Ludlow, Rethinking Conspiracy: The Political Philosophy of Julian Assange, available at Brian Leiter, Peter Ludlow on "The Political Philosophy of Julian Assange," LEITER REP.: A PHIL. BLOG (Dec. 7, 2010, 4:16 PM), http://leiterreports.typepad.com/blog/2010/12/peter-ludlow-on-the-politicalphilosophy-of-julian-assange.html. 
that all of its internal correspondence will be leaked, a powerful, secretive regime will find itself unable to communicate with the agents it needs to oversee and instruct in order to operate. It must therefore either reform itself and act ethicallyin which case transparency has in fact performed its reformist function-or collapse. Transparency, then, serves not merely to improve the state but to pose a fundamental challenge to its operations. ${ }^{210}$ No such challenge can come from within the state itself. Laws attempting to impose transparency, which by definition are drafted and enforced by government institutions, will not offer the complete exposure that the right of access to information requires. Only a wholly independent institution, one willing to deploy extralegal tactics at the leading edge of technological innovation, can do so. Rather than viewing information technology as a means to reform the state's administrative functions, WikiLeaks views its technological capabilities as a means to spur a collective political uprising that can refigure the state through popular democracy.

\section{B. The Limits of the Vigilante Fix}

Criticism of WikiLeaks as a model for transparency activism and as a proponent of a particular vision of transparency enforcement begins, typically, with the argument that it either engages in or solicits criminal activity. ${ }^{211}$ There is no question that it must rely on unauthorized and possibly illegal disclosures made by its sources. But with respect to WikiLeaks itself, the unauthorized, potentially criminal nature of these disclosures provokes one critique, one prediction, and one problem for the organization and those who follow its model: First, WikiLeaks' actions constitute or rely upon lawless actions. ${ }^{212}$ Second, its disclosures will cause harm to American military, law enforcement, and diplomatic efforts. ${ }^{213}$ And third, its reliance on unauthorized, potentially illegal disclosures makes WikiLeaks vulnerable to supply chokeholds. I want to set aside the first issue to the extent that

\footnotetext{
${ }^{210}$ ASSANGE, supra note 209, at 1 (calling for a "course of ennobling and effective action to replace the structures that lead to bad governance with something better").

${ }^{211}$ See Benkler, supra note 16, at 331-33 (summarizing official complaints about WikiLeaks as lawless and as assisting terrorists); Fenster, supra note 185, at 770-72 (summarizing FOI advocates' complaints about WikiLeaks).

212 See, e.g., Steven Aftergood, WikiLeaks Fails "Due Diligence” Review, SECRECY NEWs (June 28, 2010, 11:19 AM), http://www.fas.org/blog/secrecy/2010/06/wikileaks_review.html (leading transparency advocate declaring that "WikiLeaks must be counted among the enemies of open society because it does not respect the rule of law nor does it honor the rights of individuals"). For a thorough discussion of WikiLeaks's potential criminal liability, see Benkler, supra note 16, at 356-65.

${ }^{213}$ See Benkler, supra note 16, at 331-33 (summarizing claims made by elected and Executive Branch officials about the dangers of WikiLeaks's disclosures), 328-30 (dismissing such concerns).
} 
it conjures up the complex legal issue of WikiLeaks' criminal liability (which is beyond this article's scope), ${ }^{214}$ and the adverse effects of its disclosures, which are to date arguably minimal and which the site itself claims to mitigate through its "harm minimization" efforts. ${ }^{215}$ Instead, I will focus on the problem that WikiLeaks faces in obtaining a sufficient supply of secrets, the site's most significant vulnerability as a model to systematically force transparency upon states.

WikiLeaks necessarily relies upon the existence of whistleblowers and hackers who are willing to release information against the state's wishes and in violation of the law, a reliance that is neither particularly new nor a systematic means to make the state open. It thus confronts a problem that Daniel Ellsberg, as a Pentagon employee with security clearance and direct access to the documents he released, and with the single motivation of ending the Vietnam War, did not face after he leaked the Pentagon Papers — but would have faced had he promised to continue making unauthorized disclosures of classified documents from the American military as part of a broader effort to open all secret American government operations to public view. WikiLeaks's business model, by contrast, depends upon the ongoing availability of content, while its political program as an agent of transparency depends upon the credible threat of an endless supply of leaked documents. Unlike the FOI, anti-corruption, and digital-transparency movements, all of which seek to petition and persuade the state to change its policies and practices, WikiLeaks operates in direct opposition to the state, whose laws it at best skirts and more often openly violates in order to enforce broader international human rights. Even the minimally non-transparent state cannot accede to WikiLeaks' demands; it will inevitably attempt to control its information and stop leaks. ${ }^{216}$ If it successfully does so, then WikiLeaks and similar channels will lack supply from frustrated government employees or those who steal documents, and the model will fail while the state will remain opaque to its citizens.

As a result, even if it can solve its ongoing financial and legal problems, and even if its model is successfully adopted by well-funded institutions, WikiLeaks

\footnotetext{
${ }^{214}$ See id. at 356-65 (discussing WikiLeaks's potential legal liability).

${ }^{215}$ See Fenster, supra note 185, at 789-97.

${ }^{216}$ Notwithstanding its apparent commitment to open government, see text accompanying supra notes 148-150, the Obama administration has been especially aggressive in prosecuting leaks. See Josh Gerstein, Despite Openness Pledge, President Obama Pursues Leakers, Politico (Mar. 7, 2011), http://www.politico.com/news/stories/0311/50761.html; Carrie Johnson, Case Against WikiLeaks Part of Broader Campaign, NPR (May 11, 2011), http://www.npr.org/2011/05/11/136173262/case-againstwikileaks-part-of-broader-campaign; Jane Mayer, The Secret Sharer, NEw YoRKER, May 23, 2011, http://www.newyorker.com/reporting/2011/05/23/110523fa_fact_mayer.
} 
U N I V E R S I T Y O F P I T T S B U R G H L A W R E V I E W

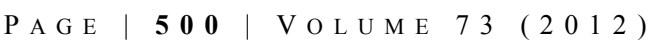

and its successors and copycats will always face a supply problem, one made more difficult when governments better secure their computer networks and security systems and harshly punish whistleblowers. ${ }^{217}$ It is possible, of course, that a thousand WikiLeaks will bloom, perhaps as small start-ups in response to new caches of documents, or that established newspapers or well-funded NGOs will be able to copy the WikiLeaks model and use it more regularly. But this scenario suggests something less than a permanent program to force transparency, especially in contrast to those advocated through law, technology, or international NGOs and IFIs, which propose permanent fixes to information asymmetry. Instead, it represents an irregular set of practices that can only be effective when sources make documents available. The risk that WikiLeaks and others will obtain and distribute documents over the Internet might affect official behavior, but it is unclear if those effects will either favor openness - for example, when state actors preemptively release documents or hold open meetings — or secrecy—for example, when officials do a more effective job of hiding their communication. The state will ultimately remain opaque except when WikiLeaks can crack it open-a dramatic but comparatively underwhelming ideal for making the state permanently and programmatically visible.

\section{Conclusion}

WikiLeaks rests its vision of a more functional and democratic state on the assumption that more disclosures will positively affect the state and public. Like FOI advocates, it views transparency as a human and political right; like anticorruption advocates, it views the state as inevitably corrupt without the monitoring that NGOs and other external institutions can provide; and like digital-transparency advocates, it views new technological developments as enabling a more visible, accountable state. But the site's commitment to vigilante disclosures of government documents, as well as its radical political project and skepticism about the online community's ability to process and distribute the information that it liberates, distinguish both its project and its vision of a truly transparent state. The state it hopes to call forth is neither the traditional one (as the FOI movement relies upon), nor the one overseen by networks of international NGOs that are in turn tied to networks of global capital (like the anti-corruption movement), nor a collaborative or minimal, market-oriented one (that digital advocates prefer), but a left-libertarian state that fully meets its international human rights obligations-obligations that

${ }^{217}$ See Fenster, supra note 185, at 764-65 (discussing the U.S. government's aggressive, if thus far unsuccessful, efforts to punish WikiLeaks, and the military's harsh incarceration of Bradley Manning as a strategy to dissuade others from leaking documents). 
WikiLeaks will enforce, if no one else will—or will suffer the legal or revolutionary consequences.

WikiLeaks's most significant leaks to date have brought the site and its founder significant celebrity and may have played some supporting role in the political upheaval in Tunisia (which, in turn, may have had ripple effects in North Africa and the Middle East during the so-called Arab Spring). But the excessive legal and financial hurdles it has faced-surely predictable, given its open animosity to state institutions and laws - have hampered its operations and raised the anticipated costs of any who would follow in the site's footsteps. And ultimately, WikiLeaks seems not to have had the kinds of effects that would support its boldest claims about its potential as an agent of transparency or about transparency's potentially radical effects. As with digital-transparency advocates, WikiLeaks's faith in its technological fix is belied by a post-technological political order that looks quite a bit like the one that preceded it.

\section{CONCLUSION: TRANSPARENCY IN SEARCH OF A FIX}

Since advocacy on transparency's behalf began in earnest during the midtwentieth century, its various movements have proceeded from the same basic assumption about the problem that their efforts hope to solve- that states and state actors seek to protect the information they collect and produce from public disclosure. These movements also share a commitment to the idea that an external authority, whether legal, technological, or institutional, can provide the necessary fix. And as I have argued here, each movement is certain that its solution will, in turn, transform the state in a manner consistent with the movement's political commitments and institutional interests.

Nevertheless, they differ in the details of the fix they propose and the state they imagine. The FOI movement has long advocated new administrative laws and enhanced judicial review of administrative agencies, with the newly disclosed information reported on by an authoritative press - an institutional arrangement that was consistent with the existing state apparatus in the post-war U.S. The anticorruption movement advocates a transnational effort, led by NGOs and IFIs, to impose administrative and legal reforms that will lead to a non-corrupt state and a functional economy - one that is open to the flow of global investment. The digitaltransparency movement advocates the expanded use of information technologies to bring about a collaborative, open, smaller, and wired state, watched over by websites, netizens, and the wired public at large. WikiLeaks envisions unauthorized leaks as a means to protect and enforce human informational rights in a constrained, secretive state.

The movements differ, too, in their relationships with the existing, flawed state they hope to change or even dismantle. Press advocates for a legal-rights 
U N I V E R S I T Y O F P I T T S B U R G H L A W R E V I E W

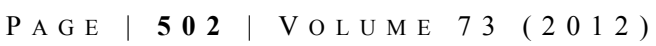

approach lobbied and collaborated with state actors, but in an effort to constrain the state in a process that included investigations and critiques of the government bureaucracy. Anti-corruption advocates collaborate with more powerful IFIs and with sympathetic state actors, but in an effort to fight what they view as state officials' inevitable tendency towards corruption. Digital-transparency advocates collaborate with tech-savvy state actors regarding technical standards and data releases while critiquing state bureaucracy and, especially, its tendencies to hoard information and to refuse to collaborate and communicate with the public. And WikiLeaks views the state as an adversary whose foundations can and must be shaken by surreptitious and perhaps criminal efforts to steal its data.

The newer transparency advocacy movements thus express, in different ways, dissatisfaction with the contemporary administrative state and with the laws intended to impose order and control over it. They envision a bounded, tamed state whose relationship to the public (and, for anti-corruption and digital-transparency advocates, the market) makes it more functional. The resulting state they envision may be smaller-indeed, perhaps it will no longer exist in its present form-but it will certainly operate more efficiently, more effectively, and, most importantly, in a more publicly accountable, more truly democratic manner. They thus work within and extend prevailing political, economic, and ideological shifts away from the post-war administrative state and towards one or more other ends: the globalization of capital, political sovereignty, and culture; the diffusion of digital technologies and networks; and a smaller, more modest role for the state in private markets and activities. Like the earlier FOI movement, they are political actors, deploying transparency to meet normative, prescriptive goals. There is, of course, nothing wrong with the political nature of transparency advocacy; advocates must persuade the public and petition government officials. But as I have tried to illustrate in this article, transparency is not a single or neutral administrative norm, despite efforts to advance it as such. Not only are its definition and limits contested, but advocates disagree over the best means to achieve it. Embedded within those disagreements are contested political ideas about the state. Not only does transparency require political advocacy, but it is, itself, a deeply political norm.

Advocacy for transparency fixes has not to date resulted in the happy ending that advocates forecast. Notwithstanding the enactment of laws and recognition of public rights to require disclosure, parts of the state remain hidden; notwithstanding the best efforts of a wide array of NGOs to unveil and stop the state's tendency towards corruption, the dream of a pure, honest government has been frustrated by the political nature of the state's operations, the financial implications of official decision-making, and local bureaucratic resistance; notwithstanding information technology's ability to move data from the state to public, government operations remain at a remove, while large swathes of the public appear unmoved by the digital magic; and notwithstanding the spectacular liberation of hundreds of 
thousands of its secret documents, the American superpower has neither been overthrown by popular revolution nor faces internal collapse. The opacity that remains despite advocates' best efforts - an opacity that indeed inhibits democracy and good governance - only demonstrates the necessity of advocates' work. Their campaigns will continue to promote a variety of fixes, with varying degrees of success - all of them reflective of, and seeking to extend, a particular normative vision of a better, more perfectly visible state. 